\title{
Konsep Jihad Dalam Perspektif Alquran (Studl Tematik Dalam Tafsir al-Kasysyaf Atas Ayat-Ayat Jihad) *
}

\author{
(THE CONCEPT OF JIHAD IN THE QUR'AN; \\ Thematic Study In Tafsir al-Kasysyaf)
}

\author{
Agus Handoko \\ Sekolah Tinggi Agama Islam PTDI Jakarta \\ Jl. Tawes No. 21-22 Tanjung Priok Jakarta Utara \\ E-mail: gushan jic@yahoo.co.id
}

\begin{abstract}
Jihad is one of the concepts of Islam are most often understood, especially by the experts and Western observers. Jihad is an integral part of Islamic discourse since the early days to contemporary Muslims. Talks about jihad and concepts put forward more or less shifting and change according to the context and environment of each thinker. Jihad in Islam is very important, so it is reasonable to set it as the Khawarij the sixth pillar of Islam.
\end{abstract}

Keywords: Verse Jihad, Tafsir, al-Kasysyaf

\begin{abstract}
Abstrak: Jihad merupakan salah satu konsep Islam yang paling sering dipahami, khususnya oleh kalangan para ahli dan pengamat Barat. Jihad merupakan bagian integral wacana Islam sejak masa-masa awal muslim hingga kontemporer. Pembicaraan tentang jihad dan konsep-konsep yang dikemukakan sedikit atau banyak mengalami pergeseran dan perubahan sesuai dengan konteks dan lingkungan masing-masing pemikir. Jihad dalam Islam sangatlah penting, sehingga cukup beralasan jika kalangan khawarij menetapkannya sebagai rukun Islam ke enam.
\end{abstract}

Kata Kunci: Ayat Jihad, Tafsir, al-Kasysyaf

* Diterima tanggal naskah diterima: 21 Juli 2014, direvisi: 25 Juli 2014, disetujui untuk terbit: 15 September 2014. 


\section{Pendahuluan}

Alquran merupakan way of life bagi umat manusia. Berisi cara-cara bermasyarakat yang berprikemanusiaan yang bisa dipergunakan untuk ruang dan waktu kapan saja. Ia diturunkan untuk memakmurkan, memajukan dan meninggikan derajat serta martabat kehidupan umat manusia di dunia, juga memberikan keberuntungan dan kejayaan di alam akhirat. Ia adalah satusatunya kitab yang membangun, membina dan memajukan secara komprehensif seluruh cita-cita umat manusia. Syariat Alquran selalu mengiringi perjalanan hidup umat manusia agar berada di jalur yang baik, mewujudkan kemaslahatan yang ditetapkan dan membina kehidupan secara umum berdasarkan prinsip dan petunjuk-Nya, serta menghantarkan tercapainya perdamaian dan kejayaan di dunia dan diakhirat.

Dewasa ini agaknya tidak ada isu tentang Islam yang sensitif yang sering diperdebatkan selain jihad. Ia diperbincangkan dalam media massa dan buku-buku akademis, baik di Timur dan di Barat. Pada saat itulah umat Islam harus cepat berpikir dan selalu mencermati perkembangan yang ada, agar selalu memberikan pemahaman yang benar terhadap ajaran jihad yang sesungguhnya, sehingga Islam menjadi agama "Rahmatan Lil 'Alamin".

Jihad juga merupakan salah satu konsep Islam yang paling sering dipahami, khususnya oleh kalangan para ahli dan pengamat Barat. ${ }^{1}$ Jihad merupakan bagian integral wacana Islam sejak masa-masa awal muslim hingga kontemporer. Pembicaraan tentang jihad dan konsep-konsep yang dikemukakan sedikit atau banyak mengalami pergeseran dan perubahan sesuai dengan konteks dan lingkungan masing-masing pemikir. Demikian sentralnya jihad dalam Islam sehingga cukup beralasan jika kalangan khawarij menetapkanya sebagai rukun Islam ke enam. ${ }^{2}$

Pentingnya ajaran jihad antara lain tercermin dalam Alquran dan hadis Nabi Saw, sebagai berikut:

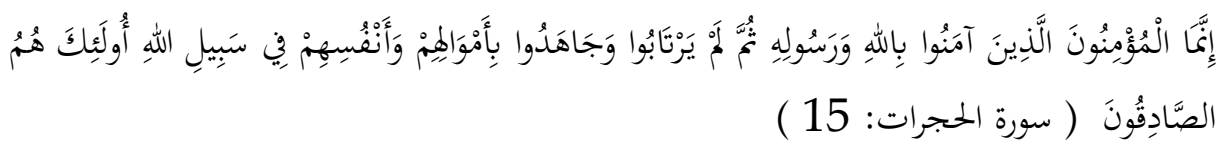

1 Sayyed Hussain Nasr, Islam Tradisi Di Tengah Kancah Dunia Modern, Terjemah Luqman Hakim ( Bandung : Pustaka, 1994 ) h.. 19

${ }^{2}$ Muhammad Chirzin, Jihad Dalam Al-Qur'an (Yogyakarta: Mitra Pustaka, 1997) h..2 


\section{Agus Handoko}

"Sesungguhnya orang-orang yang beriman hanyalah orang-orang yang beriman kepada Allah dan Rasul-Nya kemudian mereka tidak ragu-ragu dan mereka berjihad dengan harta dan jiwa mereka pada jalan Allah. Mereka itulah orang-orang yang benar." (QS. Al-Hujurat, 49 : 15)

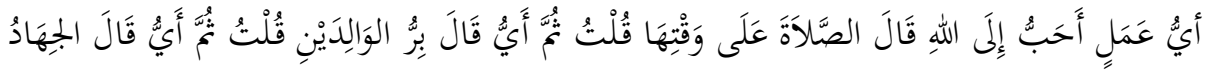

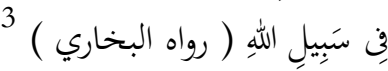

Abdullah bin Mas'ud ra berkata, "Saya bertanya kepada Rasulullah": Wahai Rasulullah, apakah amal yang paling utama? "Nabi menjawab, Shalat tepat pada waktunya, “ Kemudian apa?" Jawab Beliau, " Kemudian berbuat baik kepada kedua orangtua". Kemudian apa ? "Beliau menjawab, "Jihad di jalan Allah". Lalu saya diam. Jika saya bertanya lagi, tentu Nabi menambahkan jawaban.

Menjadi stereotip pandangan Barat, bahwa jihad fi Sabilillah adalah perang suci (Holy War) untuk menyebarluaskan agama Islam, Islam disebarluaskan melalui ketajaman pedang. Istilah the holy war itu sebenarnya tidak dikenal dalam perbendaharaan Islam Klasik. Ia berasal dari sejarah Eropa dan dimengerti sebagai perang karena alasan-alasan keagamaan ${ }^{4}$ Pandangan Barat tersebut memberi corak kepada Islam sebagai agama yang meyakini cara-cara kekerasan dan bergerak dalam kehidupan dan landasan kekejaman untuk menjauhkan manusia dari kebebasan .

Dari kalangan Islam sendiri, sejumlah orang mengartikan Jihad hanya dengan satu makna, perjuangan senjata yang menawarkan alternatif hidup mulia atau mati syahid ('isy karīman aw mut syahìdan). Bagi mereka perjuangan senjata merupakan langkah utama dan pertama.

Diskusi tentang tindakan Islam melawan ketidakadilan merupakan evaluasi penting terhadap salah satu konsep yang paling kontroversial dalam Islam yaitu jihad, biasa diterjemahkan sebagai perang suci (Holy War). Istilah Jihad bagi non muslim berkonotasi tindakan mati-matian dari orang irrasional dan fanatik yang ingin memaksakan pandangan mereka kepada orang lain tetapi, pemaksaan ini betul-betul tidak bisa dipertahankan karena Alquran menyatakan "tidak ada paksaan dalam agama." Memang dapat dikatakan bahwa penaklukan Arab yang luas pada hakekatnya politis dan ideologis.

3 Muhammad ibn Ismail Abu Abdullah al-Bukhari, al-Jami' as-shahih ( Beirut: Darul Ibnu Katsir, 1987) juz:1, h.. 197

${ }^{4}$ M.Dawam Rahardjo, Ensiklopedia Al-Qur`an : Jihad dalam Ulumul Qur`an, no 7 vol II, 1990. H..57 
Umat Islam sendiri ingin toleran terhadap masyarakat yang plural itu, sehingga ketegangan antara tirani-tirani tua itu menjadi terhenti. Islam semata-mata menawarkan kepada orang-orang di abad ke tujuh dan ke delapan sebuah kehidupan yang lebih bebas, lebih tenteram dan damai dari pada apa yang mereka alami pada masa sebelumnya. ${ }^{5}$

Kadang-kadang proses peralihan itu terjadi dengan pertukaran kepada birokrasi ketuhanan, keagamaan dan pelayanan pendidikan umat Islam. Secara historis terutama di Asia Tenggara. Islam tampak menekankan pada sikap kontinuitas (membiarkan kelestarian budaya lain) dari pada bersikap konflik dengan budaya-budaya yang ada. ${ }^{6}$

Sebagian umat Islam menganggap jihad itu sebagai rukun Islam yang keenam. Diantara mażhab fiqih, kaum khawārij menggunakan jihad untuk memaksakan pendapat mereka kepada komunitas muslim yang lain atas nama idealisme transenden dan ekstrim. Mereka bersekukuh, karena Nabi Muhammad Saw menghabiskan hidupnya dalam peperangan, maka orangorang yang beriman harus mengikuti teladannya, sehingga negara Islam harus mengatur urusan perang dan orang bid ah dipaksa untuk mengatur keyakinan seperti itu atau terkena tajamnya pedang. Tetapi bagi umat Islam yang mendasarkan perilakunya pada Alquran dan Hadis, contoh-contoh historis tercantum dalam ayat Alquran: "Perangilah di jalan Allah, mereka yang memerangi kamu tetapi janganlah melanggar batas, karena Allah tidak menyukai mereka yang melanggar batas (QS. 2 : 190).7

Menurut ayat ini agresi itu dilarang dalam Islam dan perang yang diizinkan itu mempunyai batas. Menggunakan ide yang sama, seorang jenderal purnawirawan Pakistan secara terus terang mengatakan bahwa kemampuan membunuh senjata nuklir yang menakutkan semakin parah, tidak ada tanda-tanda pengurangan. Lebih dari itu perlombaan keunggulan kualitatif dan kuantitatif semakin tidak terkendali dan gudang senjata nuklir setiap tahun semakin penuh sesak oleh senjata yang semakin canggih. Ia kemudian menyarankan agar umat Islam membuat sumbangan penuh pada usaha-usaha Internasional bagi pembatasan nuklir secara umum dan seutuhnya. Lebih jauh teknologi nuklir untuk perdamaian harus menjadi

${ }^{5}$ Abdurrahman Wahid, dkk, Islam Tanpa Kekerasan (Yogyakarta: LkiS, 1998), h. 9.

${ }^{6}$ Abdurrahman Wahid, dkk, h.10

7 Tim Depag RI, al-Qur'an dan Terjemahannya (Madinah: Mujamma' Khadim alHaramaini li Thiba atil Mushhaf asy-Syarīf, 1413) h.4 
perhatian bersama masyarakat dunia. Akhirnya umat Islam harus memperkuat diri mereka melalui kesatuan politik, pembangunan ekonomi, dan kemajuan teknologi yang diperlukan termasuk pengetahuan dalam bidang nuklir. ${ }^{8}$ Argumen menentang peperangan dan senjata nuklir itu berpangkal pada persoalan Islam dan kekerasan pada abad nuklir. Inamullah Khan berpendapat walaupun Islam membolehkan berperang, namun agama itu menekankan penggunaan kekerasan harus bersifat minimal. Kemudian perilaku umat Islam dalam peperangan harus semanusiawi mungkin.

Menurut Syeikh Abdullah bin Muhammad bin Hamid, bahwa Allah mewajibkan kaum muslimin untuk berperang dan perintah jihad sangat tegas dan kuat dalam surah-surah Madaniyah pada umumnya, seperti dalam firman Allah Ta'ala: "Berangkatlah kalian berperang baik dalam keadaan ringan maupun dalam keadaan berat dan berjihadlah dengan harta dan jiwa kalian pada jalan Allah. Yang demikian itu adalah lebih baik bagi kalian jika kalian mengetahui. (QS.9: 41). Jadi perang wajib, meskipun tidak disenangi oleh jiwa kita karena begitulah Tabi atnya. ${ }^{9}$ Menurut Abu Muhammad Jibril Abdurrahman, jihad itu adalah suatu amal yang tidak dapat digambarkan akan keindahan dan kemanisannya melainkan hanya dengan iman dan taqwa yang sebenarnya sajalah yang akan mendapat menilai dan merasakannya. Itulah jiwa seorang mujähid yang telah menyerahkan secara total seluruh miliknya berupa jiwa raga, harta dan dirinya sebagai imbalan dalam berjual beli dengan Allah SWT. ${ }^{10}$ Sedang menurut Nasir Makarim Syirazi, orangorang yang berjihad di jalan Allah yaitu yang tampil kedepan memerangi problem dan menolak hawa nafsunya serta melawan musuh-musuh yang menyimpang dengan keras, inilah yang dijanjikan Allah orang yang akan memperoleh hidayah-Nya. ${ }^{11}$

Dari berbagai pendapat para ulama tersebut, maka penulis akan mengkaji dan menganalisis secara mendalam tentang konsep jihad yang diinginkan oleh Allah Swt, sebagaimana termaktub dalam Kalam-Nya yaitu

h. 13

${ }^{8}$ Majalah.Gen. Rahim Khan, Horror of Nuclear War ( Pakistan : Defence Journal, 1984 )

9 Syeikh Abdullah bin Muhammad bin Hamid, ad-Dakwah ilal jihad fil-Qur'an wa asSunnah. Terjemah oleh Abu Ayyub al-Anshari dengan judul, Seruan jihad dalam al-Qur'an dan asSunnah (Pustaka Haraki, 1993) h.17-18

${ }^{10} \mathrm{Abu}$ Muhammad Jibril Abdurrahman, Potret Medan Jihad. Disampaikan pada Kongres Mujahidin I (Yogyakarta : Wihdah Press, 2000 M), h.3

${ }^{11}$ Nasir Makarim Sirazi, Mendalami Dasar-Dasar Akidah Islam (Jakarta: PT Raja Grafindo Persada,1997), h.151 
Alquran yang sangat jelas sebagai pedoman dan sumber hukum Islam yang harus ditaati dan dilaksanakan oleh umat Islam. Dan untuk lebih memahami apa sesungguhnya jihad tersebut, penulis akan mengkaji sebuah kitab tafsir yang sudah tidak diragukan lagi dari kalangan mufassirin akan kualitas kitab tersebut yang sampai saat ini masih dipakai dan sebagai acuan untuk menafsirkan ayat-ayat Alquran oleh para ahli-ahli tafsir dari kalangan mutaakhirīn maupun mutaqaddimīn.

Kitab Tafsir tersebut ditulis oleh seorang ulama yang bernama azZamakhsyari dengan judul al-Kasysyāé 'an Haqā' iqit Tanzil wa 'Uyūnil-Aqāwil Fi Wujūhit-Ta`wil, dengan corak tafsirnya I'tizali dan kitab tersebut merupakan salah satu di antara kitab-kitab tafsir yang mampu menyingkap tabir makna Alquran dengan cermat sehingga para pembaca dapat memahaminya dengan mudah. ${ }^{12}$ Bahwa yang dimaksud ayat-ayat jihad di sini adalah ayat-ayat yang menggunakan istilah jihad dalam Alquran, lafal jihad dan derivasinya dalam berbagai maknanya disebutkan sebanyak 35 kali, tersebar dalam 30 ayat, 16 surat. ${ }^{13}$

Ayat-ayat jihad yang berada dalam konteks perjuangan ada 28 ayat, tersebar dalam 15 surat diantaranya :Al-Baqarah (2):218, ali Imran (3):142, anNisa (4):95, al-Māidah (5):35 dan 54, al-Anfāl (8):72,74 dan 75, at-Taubah (9):16,19,20,24,41,44,73,81,86 dan 88, an-Nahl (16):110, al-Hajj (22):78, alFurqān (25):52, al-Ankabut (29):6 dan 69, Muhammad (47):31, al-Hujurāt (49):15, al-Mumtahanah (60):1, as-Shāff (61):11 dan at-Tahrīm (66):9.

Untuk lebih mempermudah pembahasan dan lebih menspesifikasikan kajian dalam penulisan ini dengan berdasarkan latar belakang masalah yang ada, maka permasalahan dapat dirumuskan sebagai berikut; Bagaimanakah Alquran berbicara tentang jihad? Bagaimanakah pendangan az-Zamakhsyari dalam kitab tafsir al-Kasysyaf atas ayat-ayat Alquran tentang jihad? Bagaimana relevansinya terhadap konteks sekarang?

${ }^{12}$ Sa'ad Abdul Wahid. Az-Zamakhsyari dan Tafsir al-Kasysyaf (Yogyakarta: IAIN SU-KA, 2000), h. 6.

13 Muhammad Fuad Abdul Baqi, al-Mu'jam al-Mufahras li Alfaz al-Qur'an al-Karìm (Beirut: Dar al-Fikr,1987), h. 182-183. 


\section{Agus Handoko}

\section{Pengertian Jihad Dalam Alquran}

Komposisi huruf jim ha dal merupakan bentuk dasar yang menunjukkan kesulitan yang berasal dari pengupayaan kekuatan dalam suatu urusan dari berbagai urusan, bisa juga dibuat pengertian yang mendekati makna ini. Dari segi bahasa, kata jih̄̄d berasal dari bahasa Arab, bentuk isim maşdar dari fi'il, jāhada artinya mencurahkan kemampuan. ${ }^{14}$ Kemudian kamus al-Munjid fillughah wal-a lam menyebutkan lafal jāhada al-`aduwwa, artinya qatalahu muhamatan 'an ad-din: menyerang musuh dalam rangka membela agama. $^{15}$

Al-jahdu juga bermakna kesungguhan dan upaya terakhir, seperti dalam firman Allah: "Dan mereka bersumpah dengan nama Allah dengan segala kesungguhan." (al-An'am: 109). Makna kata al-jahdu dan al-jihād menurut kitab lisānul'Arab yang ditulis oleh Ibnu Mandzur ialah melawan musuh, pengerahan segenap kemampuan manusia untuk mendapatkan yang diinginkan atau menolak yang dibenci. ${ }^{16}$ Sedang dalam kamus al-Munawwir yang ditulis oleh Ahmad Warson Munawwir memberikan suatu pengertian bahwa lafal jihad sebagai suatu kegiatan yang mencurahkan segala kemampuan. Apabila dirangkaikan dengan lafal fì sabìlillāh, maka diartikan sebagai berjuang, berjihad, berperang dijalan Allah. ${ }^{17}$

Sebagian orang berkata, "Penduduk Hijaz membaca al-juhdu, sedangkan yang lain membaca $a l-j a h d u$ ". Ada yang berpendapat: Bila dibaca al-juhdu artinya adalah kekuatan, dan bila dibaca al-jahdu artinya adalah kesulitan atau kesukaran. Jihad merupakan maşdar dari jahada. Bila dikatakan: Jahada Fulānun 'aduwwahu, artinya ialah fulan melawan musuhnya dengan mengerahkan usaha, atau masing-masing mengeluarkan usaha atau kekuatan untuk menolak lawannya. Jadi komposisi huruf jim ha' dal sebagaimana yang ada, menunjukkan kepada pengertian usaha yang keras dan sungguhsungguh. Jadi al-juhdu atau al-jahdu yakni pencurahan kemampuan untuk menantang sesuatu yang lain. Maka dalam syāri'at kata ini diartikan sebagai memerangi orang yang disyāri'atkan untuk diperangi dari kalangan orangorang kafir harbi dan lainnya.

14 Abu Luwis Ma'luf, al-Munjid fil-Lughah wal-`Alam (Beirut:Darul-Masyriq, 1986) h.

106.

15 Ibid

16 Ibnu Mandzūr, Lisān al- 'Arab al-Muhit, Juz I (Beirut: Dar-Lisan al- 'Arab, tth) h.521.

17 Ahmad Warson Munawwir, al-Munawwir: Kamus Arab Indonesia (Yogyakarta:Pondok Pesantren al-Munawwir, 1984) h. 234 
Pengertian jihad dalam ayat-ayat Alquran dapat dibagi menjadi beberapa jenis menurut beberapa pertimbangan. Ia bisa dibagi menurut pertimbangan alat yang dipergunakan, yang dibagi menjadi : Jihad dengan diri, jihad dengan harta dan jihad dengan lisan. Menurut hukumnya, jihad bisa dibagi menjadi jihad wajib dan jihad sunah. Menurut obyek yang dijadikan sasaran, jihad dapat dibagi menjadi : Jihad melawan nafsu, jihad melawan syetan, jihad melawan orang-orang kafir harbi dan musyrik, jihad melawan orang-orang munafik, jihad melawan orang-orang fasik dan dzalim.

Adapun jihad dengan diri, caranya dengan terjun langsung dalam kancah peperangan antara pendukung kebenaran dan kebatilan, karena hendak mengikuti perintah Allah, mengharapkan pahala di sisi-Nya, meninggikan kalimat-Nya dan menjaga eksistensi kaum muslimin. Jihad dengan harta, caranya dengan mengeluarkan harta di jalan Allah, seperti zakat, infak dan shadaqah, membantu kaum fakir miskin, membantu kaum muslimin dalam peperangan dengan mempertahankan hak-haknya. Jihad dengan lisan, caranya dengan menyampaikan perkataan yang bisa mendatangkan kemaslahatan bagi para mujahidin atau bisa menolak kehancuran dari diri mereka, seperti apapun bentuknya, bisa juga berupa dakwah dijalan Allah, dengan cara menyampaikan hujjah kepada para penentang, lalu mengajak mereka kepada jalan Allah, seperti layaknya dalam melaksanakan amar ma'ruf nahi munkar. ${ }^{18}$

Jihad dengan lisan bisa dikategorikan dalam jihad dengan jiwa. Sebab lisan merupakan bagian dari badan, sehingga jihad dengan lisan itu termasuk jihad dengan jiwa. Allah telah memerintahkan jihad dengan jiwa dan harta dalam firmannya yang berbunyi: "Berangkatlah kamu baik dalam keadaan merasa ringan ataupun merasa berat, dan berjihadlah dengan harta dan dirimu pada jalan Allah." (at-Taubah: 41).

Dilihat dari istilah syara', para fuqaha dari empat madzhab telah mendefinisikan bahwa makna jihad adalah mengerahkan kemampuan dengan sungguh-sungguh melalui harta dan jiwa dalam menegakkan agama Allah dan mempertahankannya sesuai dengan aturan hukum syara' yang berlaku. Dibawah ini akan diuraikan pengertian jihad yang dikemukakan oleh para fuqaha keempat mażhab itu. Sebagaimana yang ditulis oleh Shaheed Abdullah

18 Salman al-Audah, terjemah Kathur Suhardi. Sarana Menghilangkan Ghurbah Islam (Jakarta: Pustaka al-Kausar, 1993), h. 15-16 


\section{Agus Handoko}

Azzam yang diterjemahkan oleh Mahmod Malawi, dalam bukunya Jihad Adab dan Hukumnya, sebagai berikut:

Pertama; Hanafi. Al-Kasani mengatakan dalam kitabnya al-Bada'i, juz 9/4299 bahwa al-jihad berarti mengerahkan segenap kemampuan dan tenaga dengan melakukan perlawanan dan pertahanan dari ancaman musuh (kafir harbi), baik dengan diri, harta, maupun lisannya.

Kedua, Maliki. Makna jihad diperuntukkan kepada orang-orang muslim dengan melawan orang-orang kafir harbi yang tidak terikat dalam perjanjian (damai) demi menegakkan ajaran Allah SWT. (Lihat Hasyiah alAdawi oleh as-Shaidi, juz 2/2 dan 'Aqrabul Masālik, ad Dardir, juz 2/267)

Ketiga, Syafi'ie. Al-Baijuri mengatakan al-jihād adalah melawan musuh dari ancaman dan serangan bertujuan jihad di jalan Allah (Lihat alBaijuri, Ibnu Qasim, juz 2/261). Selain itu, Ibnu Hajar dalam Fathul Bari, juz 2/6 juga mengatakan bahwa ditinjau dari hukum syara', jihad berarti mengerahkan segenap kemampuan untuk melawan orang kafir harbi.

Keempat, Hambali. Jihad artinya melawan orang-orang kafir harbi (Lihat Mathalib Uli an-Nuha, juz 2/497). Jihad juga berarti melawan musuh dan mengerahkan segenap kemampuan untuk menegakkan kalimat Allah. ${ }^{19}$

Kata jāhada (bersungguh-sungguh) membentuk tiga kata kunci yang dapat mengantar manusia meraih predikat tertinggi sebagai manusia paripurna (insān kāmil). Jihad berarti perjuangan fisik secara optimal dilakukan untuk mencapai tujuan. Ijtihād berarti perjuangan secara intelektual yang dilakukan secara bersungguh-sungguh untuk mencapai suatu tujuan. Sedangkan mujāhadah adalah kelanjutan dari perjuangan secara fisik dan intelektual, yaitu perjuangan batin dan ruhani. ${ }^{20}$ Adapun yang dimaksud dengan jihad di sini adalah perjuangan yang dilakukan oleh seseorang dengan mengandalkan unsur fisik atau otot, meskipun perjuangan non-fisik juga termasuk dalam kategori jihad ditempat lain.

Jihad secara fisik tidak harus diukur dengan kemampuan seseorang untuk mengangkat senjata melawan musuh-musuh Islam, tetapi juga melakukan berbagai usaha secara fisik untuk mewujudkan keamanan,

19 Shaheed Abdullah Azzam, diterjemahkan oleh Mahmood Malawi, Jihad Adab dan Hukumnya (Jakarta: Gema Insani Press,1987) h. 12

${ }^{20}$ Nasaruddin Umar, Antara Jihād, Ijtihād dan Mujāhadah (Jakarta: Majalah Sufi 18, 2001) h. 35 
keselamatan dan ketinggian martabat manusia. Bahkan menyingkirkan batu kerikil di jalanan yang dapat membahayakan orang lain juga termasuk cabang dari jihad

Pada dataran realita jihad berarti perjuangan di jalan Allah; suatu bentuk pengorbanan diri. Intinya terdapat dua hal. Pertama, iman yang sungguh-sungguh dan ikhlas, yang tujuannya hanya karena Allah, sehingga segala kepentingan pribadi atau motif-motif duniawi dianggap remeh dan tidak berbekas. Kedua, kegiatan yang tidak kenal lelah, termasuk pengorbanan nyawa, pribadi atau harta benda dalam mengabdi kepada Allah SWT. Perjuangan yang hanya asal hantam, berlawanan dengan jiwa jihad yang sebenarnya. ${ }^{21}$ Bahwasanya kalau dilihat lebih jauh lagi, term "Mujāhadah" dan "Jihād" masih satu akar kata, keduanya sama-sama mashdar (kata benda abstrak) dari rangkaian kata jāhada-yujāhidu-mujāhadatan-wa jihādan.

Kedua istilah itu tersirat makna muţāwa'ah, yaitu adanya dua kutub atau dua pihak yang saling berhadapan. Kedua kutub itu, kalau dalam mujāhadatun-nafs berarti antara akal berhadapan dengan nafsu, sedangkan dalam jihādul-kuffār berarti antara kaum muslim yang berhadapan dengan kaum kafir harbi. Tetapi penggunaan kedua istilah itu tidaklah spesifik, karena istilah jihad bisa dengan menggunakan istilah jihadun-nafs (memerangi hawa nafsu) dan mujāhadatul-kuffār (memerangi kaum kafir harbi). Imam Ghazali dalam kitabnya Mukāsyafatul-Qulûb juga menggunakan istilah jihad, baik dalam konteks memerangi nafsu maupun dalam konteks melawan musuh Islam. Soalnya akan lain apabila pengertian jihad dipakai sebagai bagian dari peristiwa sejarah, umpamanya sejarah Indonesia pada masa awal kemerdekaan, dimana Bung Tomo meneriakkan "Allāhu-Akbar" melalui corong radio Surabaya sebagai seruan "Perang Suci" melawan kekuatan Kolonial, yang tidak saja membangkitkan semangat diantara kelompokkelompok Hizbullāh dan Barisan Sabîlillāh di pesantren-pesantren, tetapi juga menggerakkan seluruh bangsa Indonesia untuk mempertahankan kemerdekaan sebagai hak suci bangsa yang membebaskan diri dari belenggu penjajahan. Begitulah pengertian jihad pada masa Penjajahan, akan tetapi jihad akan diartikan berbeda ketika dalam konteks saat sekarang. Seorang ulama pujangga India dan negarawan yang sangat dihormati oleh Nehru,

${ }^{21}$ Abdullah Yusuf Ali. Al-Qur'an Terjemah dan Tafsirnya, terjemah Ali Audah (Jakarta: Pustaka Firdaus, 1993), h. 444 


\section{Agus Handoko}

Maulana Abu al-Kalam Azad, melihat pula distorsi yang berkembang disekitar pengertian jihad. Karena itu ia merasa perlu mengoreksinya.

Dalam tulisannya yang membahas soal-soal khilāfah atau pemerintahan, ia menulis mengenai pengertian jihad, telah terjadi kesalahpahaman yang serius. Banyak orang mengartikan, jihad itu ialah berperang (kekerasan). Orang-orang yang memusuhi Islam juga terlibat dalam kesalahpahaman ini. Padahal dengan pengertian ini berarti membatasi arti dari hukum yang amat luas lagi suci dan luhur. Dalam istilah Alquran dan as-Sunnah, jihad artinya usaha yang sungguh-sungguh untuk mengatasi kepentingan pribadi guna kepentingan kebenaran yang menjadi pondasi dalam kepribadian seorang muslim. Usaha ini dilakukan dengan sepenuh jiwa dan harta, dengan membelanjakan waktu, umur dan sebagainya dengan memikul macam-macam kesukaran dan juga dengan menghadapi pasukan yang menumpahkan darah. Untuk menghadapi pasukan musuh diperlukan waktu tertentu, tetapi untuk menghadapi diri pribadi bagi seorang mukmin ialah usaha seumur hidup, jihad diwaktu pagi dan sore.

\section{Jihad Pada Masa Nabi Muhammad SAW}

Sasaran jihad Nabi dan kaum muslimin antara lain orang-orang kafir harbi dan munafik sebagaimana termaktub dalam Alquran (QS. 66:9). Ayatayat jihad yang tidak menyebutkan objek, sasarannya mencakup segala sesuatu atau siapa saja yang terjangkau oleh kata tersebut, seperti seruan membaca pada ayat Alquran yang pertama kali diturunkan kepada Rasulullah SAW (QS. 96: 1-5).

Adapun ayat-ayat jihad yang mengandung maksud perjuangan sebanyak 28 ayat tersebar dalam 15 surah, terdiri dari 3 surah turun pada periode Mekkah dan 12 surah turun pada periode Madinah, dengan urutan kronologis turunnya sebagai berikut: 1. Al-Furqān $\{25\}: 52$ 2. An-Nahl \{16\}:110. 3. Al-'Ankabut \{29\}: 6, 69. Ketiga surat inilah yang turun pada periode Mekkah. Ayat-ayat Qur'an tentang jihad yang turun pada periode Madinah, sebanyak 12 surah diantara surat tersebut adalah: 1). Al-Baqarah\{2\}: 218; 2). Al-Anfāl \{8\}:72,74,75; 3). Ali Imran \{3\}:142; 4). Al-Mumtahanah \{60\}:1; 5). AnNisa ‘4\}: 9; 6). Muhammad \{47\}: 31; 7). Al-Hajj \{22\}: 78; 8). Al-Hujurāt \{49\}: 
15; 9). At-Tahrim \{66\}: 9; 10). Ash-Shāf \{61\}: 11; 11). Al-Māidah\{5\}: 35-54; 12). At-Taubah $\{9\}: 16,19,20,24,41,44,73,81,86,88 .{ }^{22}$

Jihad dalam Islam bermula sejak Rasulullah Saw, menerima wahyu pada hari Senin, 17 Ramadhan 610 M sedangkan Nabi Muhammad telah berusia 40 tahun. Langkah pertama yang dilakukan oleh Nabi, membaca fenomena masyarakat Mekkah yang mengalami dekadensi dalam segala segmen kehidupan (QS: 1-5). Kedua, menyeru kerabatnya dan warga masyarakat Mekkah secara diam-diam untuk beriman kepada Tuhan yang Maha Pemurah, mengikuti petunjuk-Nya dan menerima kehadiran Nabi sebagai Rasul (QS. 68:1-7). Langkah tersebut diambil Nabi Muhammad Saw, setelah ia dibina oleh Allah SWT melalui qiyāmullail dan pesan-pesan Alquran, tanpa meninggalkan aktifitas di siang hari yang panjang (QS.73: 1-10).

Pada usia empat puluh tahun, sekitar tahun 611 M, Nabi Muhammad mengumumkan kenabiannya di Mekkah dan menyampaikan ajarannya tentang keesaan Tuhan, yang dengan demikian membuang 360 dewa-dewi yang berada di tempat suci Ka'bah. Walaupun ia dihormati oleh orang-orang Mekkah karena kasih sayangnya, kejujurannya, kesucian karakternya, kesopanannya, kebenarannya sehingga di panggil al-Amîn (dapat dipercaya).

Kelompok dominan di Mekkah menyerang Nabi Muhammad Saw dengan fitnahan dan membiarkan siksaan tak henti-hentinya ditimpakan pada dirinya dan orang-orang yang mengikutinya. Ia pergi ke Tha if untuk berdakwah. Di sana ia lagi-lagi disiksa dan dicaci. Ia dan keluarganya diasingkan. Sepanjang periode ini ia tidak pernah mengutuk seorangpun, juga tidak pernah melontarkan pernyataan yang melecehkan seseorang. Sebaliknya ia berdoa agar hidayah dan keselamatan dianugerahkan bagi mereka. Periode penghambatan berlanjut selama dua belas tahun. Kemudian ada rencana pembunuhan terhadap dirinya sehingga ia terpaksa hijrah ke Madinah. ${ }^{23}$

Babak baru perjuangan dimulai pada tahun ketiga kenabian, setelah datang perintah Allah untuk menyiarkan ajaran Islam secara terbuka. Nabi mengingatkan manusia akan kekuasaan Allah SWT dan agar manusia berbakti kepada Allah semata. Dengan wahyu yang disampaikan secara berangsur-angsur dan setahap demi setahap (QS. 87:6; 94:8), dimana ada

${ }^{22}$ Muhammad Husain Thabataba i, Mengungkap Rahasia al-Qur'an, terjemah A.Malik Madani dan Hamim Ilyas (Bandung: Mizan, 1994) h. 124-125

${ }^{23}$ Abdurrahman Wahid, dkk. Islam Tanpa Kekerasan, (Yogyakarta: Lkis, 1998) h. 47-48 
peluang lalu Nabi masuk. Di tempat-tempat ramai atau dirumah orang. Dari situlah kemudian ajaran Islam berkembang keluar lembah sampai di Yatsrib.

Jihad periode Mekkah selama 13 tahun berakhir ketika datang perintah Allah kepada Nabi Muhammad SAW untuk berhijrah dari kota Mekkah ke Madinah, menyusul pengikut-pengikutnya yang telah meninggalkan Mekkah terlebih dahulu. Tak pernah sekalipun terjadi perang secara fisik antara kaum mulimin dengan kaum musyrik di Mekkah, walaupun sebagian pengikutnya seringkali mengalami penganiyaan secara fisik sampai dengan ajal menemuinya. ${ }^{24}$ Dalam hijrahnya menuju kota Madinah, Nabi Muhammad SAW selalu mengajak pengikutnya untuk bersabar dalam menghadapi segala cobaan yang didapatkannya, sehingga hijrah merupakan jalan untuk tercapainya kehidupan yang lebih baik bagi kaum muslimin yang tertindas dan juga menjadi sebab diperolehnya kenikmatan yang lebih besar (QS 4: 97 - 100). Suasana kota Madinah yang lembut dan watak rakyatnya yang tenang sangat mendorong penyebaran agama Islam disana. Hijrah pertama-tama berfungsi menyelamatkan kemerdekaan dan kehormatan seseorang, yang kedua hijrah jalan untuk mencapai kemungkinan-kemungkinan baru dan menemukan lingkungan yang mendukung perjuangan diluar wilayah sosial politik yang dzalim pada saat itu, untuk mengembalikan kembali dalam menentang kedzaliman tersebut untuk memperoleh kemenangan umat Islam.

Ketiga, menyebarkan aqidah dan pemikiran di wilayah lain dalam rangka menunaikan tugas risālah kemanusiaan yang universal dan melaksanakan tanggung jawab di tengah-tengah umat manusia dalam rangka menyadarkan, membebaskan dan memberikan kebahagiaan bagi mereka. ${ }^{25}$

Jihad pada periode Madinah ditandai dengan pembangunan masjid pertama di Quba' pada hari Senin, 8 Rabi,ul Awwal 1H (tahun ke-13 kenabian). Langkah selanjutnya mengubah nama Yatsrib menjadi MadinaturRasul atau al-Madinah al-Munawwarah, pendirian masjid tersebut sebagai tempat untuk beribadah dan berkumpul, mempersaudarakan orang-orang yang hijrah (Muhäjirin) dengan tuan rumah yang digelari Anshār (para penolong) serta membuat pakta perjanjian "Piagam Madinah", sebagai landasan kehidupan masyarakat yang bersumber dari risālah Islam, untuk

${ }^{24}$ Ibid

25 Muhammad, Tinjauan Normatif dan Historis Jihad dalam Islam (IAIN Yogya: Jurnal Penelitian Agama no.16, TH.VI, 1997) h. 67-68 
menetapkan hak-hak individual dan masyarakat, hak-hak berbagai kelompok dan kaum minoritas serta menyusun pertahanan yang efektif terhadap musuh dari luar yaitu orang Quraisy. Tahun kedua ditandai dengan perubahan arah kiblat, dari Yerussalem ke Ka'bah (Masjidil Harām) di Mekkah (QS 2:142-144). Dengan itu Allah mencabut kepemimpinan orang Israel dan menanamkannya kepada kaum muslimin sebagai karunia dari-Nya (QS 2:150). Tahun-tahun berikutnya diwarnai dengan berbagai pertempuran yang tak terhindarkan. ${ }^{26}$

Sirāh Nabi Muhammad SAW yang harum telah menyajikan contohcontoh yang mengagumkan tentang keberanian beliau pada masa damai maupun perang, kejantanan beliau mengundang decak kagum. Pada saat-saat damai beliau adalah seorang pemimpin yang menciptakan kesatuan diantara manusia agar mereka siap berjihad di jalan Allah SWT. Pada waktu perang beliau seorang pemimpin yang langsung andil dalam kancah peperangan karena dorongan tauhid. Perjalanan hidup beliau berupa tauhid untuk jihad dan jihad untuk tauhid. Hasil perjuangan jihad dan tauhid beliau adalah bersatunya seluruh wilayah Arab di bawah bendera Islam, sekalipun perjuangan tersebut diwarnai dengan peperangan. ${ }^{27}$

Adapun peperangan dalam melawan orang-orang kafir harbi Quraisy yang beliau hadapi pada periode Madinah diantaranya perang Badar, perang Uhud, perang Khandak dan Hunain serta perang-perang yang lainnya. Pada sisi lain harus menyingsingkan dari kesulitan bangkit, melawan tatanan yang bersifat sewenang-wenang, yang berlawanan dengan kaedah kebenaran dan keadilan dan prinsipnya yang abadi, tidak rusak dan tidak akan pupus kesungguhannya dalam memperjuangkan ajaran Islam.

Kesuksesan Islam yang belum pernah terjadi dalam sejarah ini "disebabkan oleh revolusi yang bermakna dan kemampuannya untuk memimpin massa keluar dari situasi keputusasaan yang diciptakan oleh kebusukan peradaban kuno, bukan hanya Romawi dan Yunani tetapi juga Persia, Cina dan India". Dalam waktu yang amat pendek, Arab yang terpecah belah bisa bersatu di bawah satu bendera. Mereka melumpuhkan kebesaran para kaisar dan para Kisra. ${ }^{28}$ Sehingga nama besar beliau dalam

${ }^{26}$ Ibid

${ }^{27}$ Mahmud Syait Khathab, Latar Belakang Kemenangan Islam. Terjemah Kathur Suhardi (Solo: Pustaka Mantiq, 1992) h. 120

${ }^{28}$ Abdurrahman Wahid, dkk ......... h. 50 
perjuangannya menegakkan agama Islam tetap selalu diingat oleh umat Islam di seluruh dunia.

\section{Istilah-istilah yang Semakna dengan Jihad}

Untuk menjadikan makna jihad dalam konsep Islam yang sesungguhnya, maka penulis akan mengutip ayat-ayat Alquran yang membicarakan masalah-masalah yang berkaitan tentang jihad. Karena bagaimanapun juga istilah-istilah yang semakna dengan jihad akan membuka wawasan untuk memahami lebih jauh lagi terhadap pandangan dunia akan konsep jihad dalam Islam.

Adapun istilah-istilah tersebut akan diambil dari ayat-ayat Alquran yaitu al-Harb, al-ghazwah dan al-Qatl, karena ketiga kata tersebut sangat berkaitan erat dengan kata jihad yang sering dimaknai secara sempit dengan istilah perang. Ketiga istilah tersebut adalah:

Pertama, Kata al-harb atau War adalah peperangan yang berkecamuk antara dua negara atau lebih, untuk mencapai tujuan-tujuan politik dan ekonomi, dengan menggunakan kekuatan senjata. ${ }^{29}$ Sedangkan menurut Muhammad Farid Wajdi, harb diartikan penghancuran kekuatan musuh secara keseluruhan, dalam keadaan apapun. Perang tersebut akan diakhiri dengan kepedihan dan kesengsaraan yang menghancurkan segala aspek kehidupan..$^{30}$ Tujuan pokok dari peperangan adalah menghancurkan kekuatan musuh, baik secara militer maupun bangsa, agar tidak lagi mampu bangkit dan menerima syarat yang ditawarkan pihak pemenang. Menghancurkan kekuatan musuh mencakup penghancuran terhadap kekuatan material dan spritualnya. Inilah diantara pengertian secara ringkas yang biasa dipakai dikalangan militer. Pengertian semacam ini perlu diketahui oleh orang-orang Islam, terutama setelah meletusnya perang pada Juni $1967 .{ }^{31}$ Yang jelas, tujuan peperangan secara praktis dan yang paling pokok adalah mengalahkan fisik manusia.

Kata al-harb selalu disebut dalam ayat-ayat Alquran sebanyak empat kali, dengan makna al-qitāl. Diantara ayat-ayat tersebut adalah :

29 Ibid

30 Muhammad Farid Wajdi, Dairatu Ma`arif al-Qarnil Isyruna ar-Rabi Asyara wa alIsyruna. Jilid III (Beirut : al-Maktabah al-Ilmiyyah al-Jadidah, tth) h. 389

${ }^{31}$ Mahmud Syahith Khattab, ......... h. 61 
“Dan Kami telah timbulkan permusuhan dan kebencian diantara mereka (orang-orang Yahudi) sampai hari kiamat. Setiap mareka menyalakan api peperangan, Allah memadamkannya dan mereka berbuat kerusakan dimuka bumi dan Allah tidak menyukai orang-orang yang membuat kerusakan." (alMaidah, 5 : 64). "Jika kamu menemui mereka dalam peperangan, maka cerai beraikanlah orang-orang yang dibelakang mereka dengan (menumpas) mereka, supaya mereka mengambil pelajaran."(al-Anfal, 8 : 57). "Apabila kamu bertemu dengan orang-orang kafir harbi (di medan perang) maka pancunglah batang leher mereka. Sehingga apabila kamu telah mengalahkan mereka maka tawanlah mereka dan sesudah itu kamu boleh membebaskan mereka atau menerima tebusan sampai perang berhenti...." ( QS.Muhammad, $47: 4)$

Adapun perang dalam Islam memiliki tujuan yang hakiki. Perang dalam Islam bukanlah sebagaimana perangnya para imperialis yang berambisi memperluas daerah kekuasaan, memusnahkan manusia, peradaban, kebudayaan dan moralitas. Mereka mengeksploitir negeri jajahan, lalu menancapkan ideologi dan kekuasaan pada penduduknya dengan caracara paksaan. Sebaliknya perang dalam Islam membawa misi kebenaran, kemanusiaan dan kehormatan manusia. Dan tujuan perjuangan Islam bukanlah untuk kepentingan pribadi pejuangnya bahkan bukan terbatas untuk kepentingan kaum muslimin, melainkan untuk kemaslahatan umat manusia dimuka bumi.

Kedua, Kata al-qatl maşdar dari "qatala" yang artinya peperangan atau pertempuran dan bisa juga diartikan sebagai pembunuhan yang disengaja atau pembunuhan yang tidak disengaja. ${ }^{32}$ Dalam ayat-ayat Alquran disebut sebanyak 171 kali, diantaranya membicarakan masalah-masalah peperangan dan pembunuhan. ${ }^{33}$ Peperangan dalam syari'at Islam bukanlah untuk memaksa manusia memeluk agama Islam, bukan pula berupa penaklukan, untuk memperluas daerah kekuasaan. Perang itu diizinkan hanyalah untuk membela diri dari serangan musuh, membalas serangan, mempertahankan kemerdekaan memeluk agama, melenyapkan tekanan terhadap agama Islam dan kaum muslimin. Juga untuk menyelamatkan umat manusia dari penindasan dan kekejaman yang datang dari pihak manapun.

${ }^{32}$ Ahmad Warson Munawwir, ......... h. 1091

${ }_{33}$ Muhammad Fuad Abdul Baqi, al-Mu'jam al-Mufahras li alfaz al-Qur'an al-Karim (Beirut: Dar al-Fikr, 1987), h. 677-681 
Oleh sebab itu, salah besar orang yang menggambarkan Nabi Muhammad SAW. dalam perjuangannya mengembangkan Islam, dengan pedang terhunus ditangan kanan dan Alquran ditangan kiri, merupakan paksaan dan kekerasan supaya orang memeluk agama ini. Yang benar ialah : "Dengan Alquran, ajaran Islam dikembangkan dan dengan pedang, agama Islam dan umatnya dipertahankan."

Walaupun demikian, peperangan disuruh berhenti apabila musuh yang menyerang telah mengundurkan diri atau telah menawarkan perdamaian. Ketika itu, kalau peperangan masih diteruskan berarti melanggar batas, dan hal itu sangat dilarang oleh ajaran Islam. Setelah peperangan usai, hubungan kembali seperti biasa, tidak boleh ada permusuhan, kecuali terhadap orang-orang yang berusaha mengganggu hubungan baik antara satu dengan yang lain. Disamping diadakan aturan perang, diadakan pula aturan berkenaan dengan tawanan perang.

Dibolehkan memerangi kaum yang melanggar perjanjian tidak serang menyerang, kaum yang membela dan mengadakan tekanan terhadap agama Islam. Kepada mereka yang tewas dalam peperangan itu, dijanjikan Allah masuk kedalam surga. Dilarang berhati lemah dan penakut, karena hal itu menjadi pokok kekalahan yang menimbulkan tekanan dan kehinaan. Diperintahkan memperkuat pertahanan untuk melawan musuh, berupa persenjataan, perbekalan, latihan dan semangat perjuangan mempertahankan diri dari serangan, sehingga dapat menggentarkan musuh Allah dan musuh kaum muslimin. Segala pengorbanan untuk itu akan dibayar cukup oleh Allah dengan pahala yang berlipat ganda.

Kaum muslimin tiada dihalangi berbuat baik, mengadakan hubungan baik dan kerja sama, dengan orang-orang yang bukan Islam, asal saja mereka tidak mengganggu kemerdekaan kaum muslimin dan tidak merintangi agama Islam serta tidak menolong musuh yang hendak mencelakakan kaum muslimin. Islam itu agama perdamaian. Ini dapat dibuktikan dengan ajaranajaran yang terkandung dalam ayat-ayat Alquran. ${ }^{34}$ Berikut ini ayat-ayat Alquran tentang al-Qatl menurut klasifikasinya, sebagai berikut:

1. Perang mempertahankan diri dari serangan

${ }^{34}$ Fahrudin HS, Ensiklopedia al-Qur'an Jilid II (Jakarta: Rineka Cipta, 1992) h. 257-258 
“Perangilah dijalan Allah orang-orang yang memerangi kamu dan janganlah melanggar batas. Sesungguhnya Allah tidak menyukai orang-orang yang melanggar batas."(al-Baqarah, 2 : 190)

2. Perang membalas serangan

“Diizinkan (berperang) kepada orang-orang yang diperangi, disebabkan mereka teraniaya. Sesungguhnya Allah itu Kuasa menolong mereka." (al-Hajj, 22 : 39)

3. Menentang penindasan

“Mengapa kamu tidak hendak berperang dijalan Allah, padahal orang-orang yang lemah dari kaum laki-laki, perempuan dan anak-anak telah berdo'a: Wahai Tuhan kami ! Keluarkanlah kami dari negeri ini, yang pendukungnya melakukan penganiayaan! Berilah kami perlindungan dari sisi Engkau dan berilah kami penolong dari sisi Engkau. (an-Nisa', $4: 75$ )

4. Mempertahankan kemerdekaan beragama

“Dan bunuhlah mereka dimana saja kamu dapati dan usirlah mereka dari tempat dimana kamu telah diusirnya. Fitnah (tekanan terhadap Kemerdekaan beragama) itu lebih berbahaya daripembunuhan. Dan janganlah kamu perangi mereka di Masjid Suci (Masjidil Haram), kecuali kalau mereka memerangi kamu disitu. Tetapi kalau mereka telah memerangi kamu, bunuhlah mereka. Begitulah pembalasan terhadap orang-orang yang tidak beriman." (al-Baqarah, 2 : 191)

5. Menghilangkan tekanan terhadap agama

“Dan perangilah mereka sampai habis fitnah (tekanan terhadap agama) dan agama itu tulus untuk Allah. Tetapi kalau mereka telah berhenti memerangi kamu, maka usailah permusuhan, selain terhadap orang-orang yang melanggar aturan." (al-Baqarah, 2 : 193)

6. Memerangi orang yang memulai perang

“Mengapa tidak kamu perangi kaum yang melanggar perjanjian dan mereka telah memutuskan hendak mengusir Rasul dan mereka pula yang mulai memerangi kamu. Takutkah kamu kepada mereka ? Allah yang lebih patut kamu takuti, jika kamu betul-betul orang yang beriman." (al-Baqarah, 2 : 13) 
Ketiga, Adapun kata al-ghazzu, dapat diartikan sebagai suatu usaha untuk menghadapi musuh dalam berperang. ${ }^{35}$ Oleh karena itu kalimat alghazzu dalam ayat Alquran disebut hanya satu kali yaitu :

"Hai orang-orang yang beriman, janganlah kamu seperti orang-orang kafir harbi (orang-orang munafik) itu, yang mengatakan kepada saudara-saudara mereka apabila mereka mengadakan perjalanan dimuka bumi atau mereka berperang: kalau mereka tetap bersama-sama kita tentulah mereka tidak mati dan tidak dibunuh."(Akibat dari perkataan dan keyakinan mereka) yang demikian itu, Allah menimbulkan rasa penyesalan yang sangat didalam hati mereka. Allah menghidupkan dan mematikan. Dan Allah melihat apa yang kamu kerjakan."( Ali 'Imran, $3: 156$ )

Ayat ini ditujukan kepada orang yang beriman, supaya tidak terpengaruh atas bujukan orang-orang munafik yang selalu menghalanghalangi kaum mukmin untuk berperang. Jadi istilah al-harb, al-qatl dan alghazzu menurut bahasa adalah peperangan, pertempuran dan pembunuhan. Sedangkan yang digunakan dalam ayat-ayat Alquran, merupakan makna yang mengandung arti memerangi musuh-musuh Allah dan umat Islam serta istilah ini juga dapat diartikan sebagai penegakkan kalimat Tauhid dengan berpegang teguh kepada kebenaran.

Adapun perbedaan istilah-istilah tersebut dengan makna jihad, alharb, al-qatl dan al-ghazzu merupakan peperangan secara fisik melawan orang-orang kafir harbi, sedangkan jihad bermakna melawan musuh-musuh Allah dan kaum muslimin, baik yang dilakukan secara fisik maupun non fisik.

\section{Jihad Menurut Az-Zamakhsyari Dalam Tafsir Al-Kasysyaf}

Nama lengkap az-Zamakhsyari, didapatkan dari berbagai data dan keterangan namun penulis mengutip satu dari beberapa data yang dikedepankan oleh Ibnu Hajar al As-qalani sebagai pentahkik, menyebut nama lengkap az-Zamakhsyari dengan Abi al-Qasim Jār Allah Mahmud Ibnu Umar az-Zamakhsysri al-Khawarizmi. ${ }^{36}$ Hampir senada dengan pendapat diatas adalah Husain Az-Zahabi mengedepankan bahwa nama lengkap azZamakhsyari adalah Abu al-Qasim Mahmud bin Umar bin Muhammad bin Umar al-Khawarizmi al-Imam al-Hanafi al-Mu'tazili, yang mendapat sebutan

${ }^{35}$ Kamil Salamah ad-Daqas, Ayatul Jihād fì al-Quran al-Karìm. (Kuwait : Dar al-Bayan, 1972) h. 11

${ }^{36}$ Ibnu al-Manzūr, Lisān al-Arab (Beirut : Dār al-Lisan al-'Arab, tt), h. 4 
"Jār Allah". ${ }^{37}$ Tentang waktu dan tempat lahir az-Zamakhsyari ada beberapa penjelasan, namun penulis mengedepankan satu dari beberapa penjelasan tersebut. Menurut Husain az-Zahabi bahwa az-Zamakhsyari dilahirkan pada bulan Rajab tahun 467 di desa Zamakhsyar daerah khawarizm. ${ }^{38}$ Sedang E.J Brill's dalam bukunya first Encyclopedia of Islam menyebutkan lebih lengkap bahwa Az-Zamakhsyari, lahir di daerah Khawarizm pada tanggal 27 Rajab 467 atau bertepatan dengan 8 Maret 1075 M. ${ }^{39}$

Berdasarkan penjelasan di atas maka dapat disimpulkan secara lengkap bahwa az-Zamakhsyari aslinya bernama Abu al-Qasim Jar Allah Mahmud bin Umar bin Muhammad bin Umar az-Zamakhsyari alKhawarizmi al-Imam al-Hanafi al-Mu'tazili di lahirkan di Zamakhsyar Khawarizm, pada hari Rabu tanggal 27 Rajab tahun $467 \mathrm{H}$ yang bertepatan dengan tanggal 8 Maret $1075 \mathrm{M}$.

Beberapa data yang menyebutkan tentang tempat dan waktu wafat Az-Zamakhsyari, namun penulis mengambil satu di antara beberapa data yang ada, data yang dimaksud adalah pendapat yang di kemukakan oleh E.J Brill's yang bersumber dari Ibnu Battuta bahwa beliau meninggal di AlJurjaniyah di Khawarizm pada hari Arafah tahun 538 H ( 14 Juni 1144 M ) dalam sumber yang sama pula diketemukan kuburannya di sana. ${ }^{40}$ Dengan demikian pada saat wafatnya, beliau berusia 70 tahun 4 bulan 12 hari .

Data yang diperoleh tentang keluarga az-Zamakhsyari diperoleh dari berbagai sumber misalnya dari Ibnu Hillikan, Abul Fattah al-Hambali, azZahabi atau E.J Brill's menyebutkan bahwa orang tua (ayah) dari AzZamakhsyari adalah Umar dan kakeknya Muhammad serta kakek buyutnya adalah Umar. ${ }^{41}$ Dalam pada itu al-Juwaini tidak menjelaskan nama ayah AzZamakhsyari, namun data-data lain yang didapatkan tentang ayahnya antara lain yaitu disebutkan bahwa ayah Az-Zamakhsyari dikala mudanya merupakan tokoh ilmuwan yang memiliki peradaban tinggi, kuat aqidahnya, tekun ibadahnya, berpuasa disiang harinya dan shalat lail di malam harinya,

37 Muhammad Husain az-Zahabi, At-Tafsīr wa Al-Mufassirūn, Jilid I (Cairo: Dar alKutub al-Hadisah, Cet II 1976 ) h.429

${ }^{38}$ Ibid, Juz I h..429-430

${ }^{39}$ E.J Brill's, First Encyclopedia of Islam 1913-1936, Volume VIII ( Leiden, New York, Kobenhavn, Koln 1987 ) h..1205

${ }^{40} \mathrm{Ibid}$, Volume VIII h. 1205

${ }^{41}$ Abul Abbas Syamsuddin Ahmad Ibn Muhammad Ibn Ali Bakr Ibn Hillikan, Wafayatul'Ayan wa Abnau Abnaiz Zaman (Beirut: Dar as-Shadir, tt ) h. 171 
sehingga akhlaknya terpuji walaupun miskin ayah Az-Zamakhsyari pernah dipenjara karena sebab-sebab politik sehingga dia meninggal dalam penjara tersebut. ${ }^{42}$ Sedangkan nama ibu Az-Zamakhsyari, semua sumber data tersebut yang disebutkan di atas tidak menyebutkan nama ibu Az-Zamakhsyari, hanya data dari Ibnu Hillikan dan al-juwaini menjelaskan sedikit keterangan mengenai sifat ibunya yang baik budi pekerti, baik pergaulan, dan menyayangi terhadap anaknya ${ }^{43}$.

Dari penjelasan dan uraian di atas, bisa disimpulkan bahwa latar belakang keluarga Az-Zamakhsyari merupakan keluarga yang baik dan religius serta dibesarkan dari keluarga yang berilmu agama tinggi serta terpuji kepribadiannya, penyandang sebagai mujahid meskipun dalam keadaan hidup serba kekurangan materi. Sebagaimana telah dijelaskan di atas, bahwa az-Zamakhsyari dilahirkan di Zamakhsyar daerah Khawarizm. Daerah ini sejak lama merupakan daerah yang memiliki ghirah yang sangat besar dalam menunjukan kebudayaan, yang terbukti sejak abad kedua Hijriyah hingga keenam Hijriyah. (abad ke-8 M hingga 11 M.), merupakan abad berkembangnya kebudayaan Iran Kuno. Daerah tersebut adalah daerah yang sangat luas dan memiliki beberapa kota yang dalam waktu lama menunjukkan kemakmuran ekonomi karena banyak di tumbuhi pohon-pohon yang berbuah dan menarik minat para pedagang untuk datang mengadakan transaksi jual-beli.

Dari suasana sosial ekonomis dan keagamaan yang baik itulah mendorong munculnya orang-orang yang berkiprah dalam bidang bahasa, sastra Arab serta bidang keagamaan lainnya, sehingga penduduk daerah Khawarizm merupakan penduduk yang luas cakrawala berpikir dalam ilmunya. ${ }^{44}$ Dalam hal itu, pada saat dilahirkannya az-Zamakhsyari pemerintahan dipegang oleh Khalifah Abul Fattah Malkasyah dengan Perdana Mentri Nizamul-Mulk yang merupakan tokoh agamis yang senang mengadakan diskusi ilmu pengetahuan yang di datangi oleh para ahli agama, baik para ahli Alquran (Qura'), ahli fiqh (Fuqaha) dan ahli hadis (Muhaddis), bahkan membangun madrasah-madrasah di berbagai kota khusus memperdalam ilmu hadis yang beliau sendiri ikut aktif mendiktekannya

42 Al-Juwaini Musthafa as-SAWi, Manhajuz Zamakhsyari fi Tafsiril Qur'ani wa Bayani 'ijazih (Mesir: Daar Ma'arif, 1968) h. 23.

${ }^{43} \mathrm{Ibid}, \mathrm{h} .25$

${ }^{44}$ Ibid, h. 17-18 
sehingga muncul beberapa usaha percetakan kitab-kitab yang berkualitas tinggi. ${ }^{45}$

Pengalaman hidup Az-Zamakhsyari di bidang pendidikannya adalah merupakan pengalaman hidup yang penuh kedinamisan, sebagaimana telah disebutkan oleh para sejarawan. Menurut Abul Fattah al-Hambali bahwa AzZamakhsyari awal mulanya belajar di Bagdad kepada Ibnu Thabar, kemudian kepada beberapa Syaikh di Mekkah dan menetap di sana beberapa lama, sehingga mendapatkan nama panggilan "Jar Allah" (Tetangga Allah). ${ }^{46}$ Lalu kembali lagi ke Bagdad untuk mengaji kepada ulama fiqh Hanafiyah yang bernama ad-Damgani serta terakhir melakukan tanya jawab dengan Abi Thahir as-Salafi, seorang ulama Iskandariah lewat surat menyurat melalui orang-orang yang naik haji ke Mekkah. ${ }^{47}$ Sedangkan menurut Ibnu Hillikan, setelah sampai umur sekolah Az-Zamakhsyari mula-mula pergi ke Bukhara untuk mencari ilmu, sehingga dalam perjalanannya ia jatuh dari kendaraan dan kakinya patah. Disamping itu ia belajar ke Mekkah dengan menetap di sana dalam masa yang cukup lama, sehingga ia memperoleh sebutan "Jar Allah" kemudian ia belajar juga ke Bagdad pada ulama dan ahli fiqh bermazhab Hanafi yang bernama ad-Damgani. Dalam kesempatan itu pula ia mengadakan wawancara ilmiah dengan al-Hafiz Abu Thahir Ahmad Ibn Muhammad as-Salafi dari Iskandariah. ${ }^{48}$

Guru yang paling dekat dengan Az-Zamakhsyari ketika masih muda adalah ad-Dabbi. Hubungan antar dia dengan gurunya tidak sekedar hubungan ilmu, melainkan lebih dari itu. Gurunya yang baik itu juga membantu biaya hidup dan memelihara dari hambatan dan kesusahan yang menimpanya. Ad-Dabbi adalah seorang ulama yang sangat dekat hubungannya dengan mentari Nizamul-Mulk. Setelah melihat kepandaian Az-Zamakhsyari dan kegigihannya dalam membela Mu'tazilah, maka ia memperkenalkan Az-Zamakhsyari dengan Nizamul-Mulk agar mendapatkan fasilitas yang memadai.

Pada masa kekuasaan Maliksyah ia memperluas hubungannya dengan para umara, namun tujuannya bukanlah harta dan kedudukan,

${ }^{45} \mathrm{Ibid}, \mathrm{h} .23-24$

${ }^{46}$ Syamsuddin Muhammad Ibn Ali Ibn Ahmad ad-Dawudi, Thabaqat al-Mufassirin Juz II (Beirut : Daar al-Kutb al-Ilmiah 1403 H / 1983 M) h. 315

47 Al-Hambali Abul Fattah Abul Hay Ibn Ahmad, Syajaratuz Zahab fi Akhbati Man Zahab (Beirut Maktabah at-Tijarati li at-Tiba'ati wa an-Nasyri wa at-Tauzi, 1961) h. 118

48 Ibnu Hillikan, op.cit h. 169-170 
melainkan ilmu pengetahuan. Karena apa yang dicita-citakan tidak dapat menjadi kenyataan, maka ia sangat kecewa dan minta izin kepada NizamulMulk untuk meninggalkan negaranya, menuju ke Khurasan untuk mencapai cita-citanya. ${ }^{49}$

Di Khurasanpun tidak berhasil mencapai apa yang diharapkannya. Kemudian pindahlah ia ke Afsahan, daerah kekuasaan Sultan as-Saljuqi Muhammad bin Abi al-Fath Maliksyah yang wafat pada tahun $511 \mathrm{H}$, sultan yang pemberani dan banyak amal shalihnya. Pada tahun $512 \mathrm{H}$, azZamakhsyari sakit keras, hingga mengendorkan cita-citanya untuk meraih ilmu dan kedudukan yang tinggi. Ketika itu ia berjanji kepada Allah tidak akan menginjak lagi pintu Sultan atau memujinya atau mengharapkan suatu kedudukan apapun. Setelah sembuh dari sakitnya, ia segera meninggalkan Asfahan dan menuju ke Bagdad. Di sana ia belajar hadis kepada Abi alKhattab bin al-Battar, Abi Sa'ad asy-Syafani , Syaihul Islam dan Abi Mansur al-Harisi. Adapun tentang figh ia berguru kepada ad-Damgani dan asy-Syarif bin asy-Syajari. Ia ingin membersihkan diri dari dosa-dosanya, yaitu dosa keinginan meraih kedudukan dan fasilitas dari para pemimpin dan pejabat kerajaan. ${ }^{50}$

Kemudian ia berangkat ke Mekkah untuik meneruskan menuntut ilmu. Di Mekkah ia bertemu dengan 'Ali bin 'Isa bin Hamzah bin Wahhas, seorang ulama dan bangsawan Mekkah yang mempunyai kedudukan yang tinggi dan tulisan-tulisannya yang bermutu, baik berupa puisi maupun prosa. Ia tinggal di Mekkah selama dua tahun, dan mempelajari kitab Sibawaihi atas bimbingan Abdullah bin Talhah al-Yabiri. Karena kerinduannya kepada kampung halamannya, ia meninggalkan Mekkah dan kembali ke Khawarizm. Tidak berapa lama, ia merasa tidak tentram karena kerinduannya kepada Mekkah. Akhirnya ia meninggalkan kampung halamannya menuju Mekkah yang kedua kalinya. Pada kepergian yang kedua ini ia mencoba singgah di Syam, dan disana ia bertemu dengan Tajul-Mulk.

Sampailah ia di Mekkah pada tahun $526 \mathrm{H}$ dan tinggal di Mekkah pada kesempatan yang kedua ini selama tiga tahun. Pada kesempatan inilah ia menyusun tafsirnya yang berjudul "Al-Kasysyaf" hingga selesai, dan berhasil mengumpulkan syair-syairnya dalam kitab Diwanul Adab, atas saran dan bimbingan Ibnu Wahhas. Adapun salah satu kutipan syair yang ditulis

\footnotetext{
${ }^{49}$ Al-Juwaini, op.cit h. 33

$50 \mathrm{Ibid}$, .h. 35
} 
oleh az-Zamakhsyari mengenai kitab tafsirnya; "Sesungguhnya kitab-kitab tafsir di dunia ini tanpa ada batasan, dan bukanlah di dalamnya umurku yang sebanding Imam Syafi'i. Jika engkau masih menginginkan petunjuk maka bacalah kitab tersebut, sesungguhnya kebodohan itu seperti penyakit dan kitab al-Kasysyaf seperti obatnya". ${ }^{51}$ Kemudian datang lagi kerinduannya kepada kampung halamannya, dan segera ia meninggalkan Mekkah. Dalam perjalanan pulang, ia singgah di Bagdad pada tahun $533 \mathrm{H}$. Disanalah ia bertemu Abi Mansur al-Jawaliqi, seorang ulama yang terkenal di Bagdad. Demikianlah perjalanan az-Zamakhsyari dalam menuntut ilmu, hingga menjadi ulama besar pada masanya.

Husain az-Zahabi memaparkan bahwa az-Zamakhsyari seorang ahli dalam bidang tafsir, tata bahasa dan sastra Arab dan pengarang buku-buku yang sangat bermutu dalam ilmu pengetahuan. ${ }^{52}$ Ibnu Hajar al-Asqalani megemukakan, bahwa Zamakhsyari merupakan ulama yang alim dalam bidang tafsir, bahasa, sastra Arab dan hadis. ${ }^{53}$ Mustafa al-Juwaini menerangkan dengan beberapa penilaian tentang az-Zamakhsyari sesungguhnya ia seorang yang ahli dalam bidang tata bahasa, sastra Arab dan tafsir. ${ }^{54}$ Setelah data-data yang menerangkan tentang kepribadian azZamakhsyari maka dapat kita ketahui bahwa setelah selesai studinya di berbagai tempat maka ia menjadi seorang ilmuan dalam berbagai bidang ilmu pengetahuan, khususnya dalam bidang sastra dan bahasa.

Az-Zamakhsyari telah menghabiskan sebagian besar hidupnya untuk memperdalam ilmu dan mengembangkannya dengan menyusun buku-buku ilmiah. Dalam pengembangan ilmu pengetahuan, juga melalui ceramahceramah dan pendidikan formal, maka didirikan madrasah-madrasah di berbagai tempat. Kesibukan di madrasah dan dalam masyarakat untuk menyampaikan ceramah-ceramahnya, tidaklah menjadi penghalang bagi azZamakhsyari untuk menulis karya ilmiah yang tidak sedikit jumlahnya. Menurut ad-Dawudi karangan-karangan az-Zamakhsyari yang ditulis sebanyak 32 kitab dan juga menurut al-Juwaini, karya ilmiahnya tidak kurang dari 50 kitab dari berbagai disiplin ilmu pengetahuan, antara lain :

51 Ad-Dawudi, op.cit h. 316

52 Az-Zahabi, op.cit h. 430

53 Al-Asqalani, op.cit h. 57

${ }^{54}$ Al-Juwaini, op.cit h. 45 


\section{Agus Handoko}

1. Bidang Tafsir: al-Kasysyaf 'an Haqaiqit-Tanzil wa 'Uyunil-Aqawil fi Wujuhit-Ta'wil. Kitab ini adalah karya az-Zamakhsyari yang terbesar diantara karya-karya lainnya.

2. Di bidang Hadis dan fiqh: Kitab al-Faiq fi Gharibil-Hadis, ar-Ra'id fi al-Fara'id wa al-Minhaj fi al-Usul.

3. Di bidang Akhlak : Kitab Mutasyabih Asma' ar-Ruwat, fi Manaqib alImam Abu Hanifah, al-Kalim an-Nawabig fi al-Mawaiz, atwaq azZahab fi al-Mawaaiz, Nasa'ih al-Kibar, Nasa'ih as-Shighar, Maqamat fi al-Waz, ar-Risalah an-nasihah, Syarhu Maqamatih.

4. Di bidang Sastra, puisi maupun prosa : Rabi'ul Abrar fi al-Adab wa alMuhadharat, Kitab Tasliyah ad-Darir, Diwan ar-Rasail, Diwan Syi'ir, Syafi' al-'Ayyi min Kalam asy-syafi'i.

5. Di bidang Ilmu Nahwu: Nukatul Arab fi Gharibil-I'rab fi Gharibil I'rabil-Qur'an, an-Namujaz fi an-Nahwi, al-Amail fi an-Nahwi, Hasyiyah 'ala al-Mufassal fi an-Nahwi, Syarah fi Kitabih Sibawaihi, alMufrad wa al-Murakkab.

6. Di bidang Lughah: Samīm al-'Arabiah, Kitab Asas al-Balāghah, Jawāhir al-Lughah, Kitab al-Ajnas, Muqaddamah al-Adab fi alLughah, al-Asma' fi al-Lughah, al-Qisthas fi ar-Rud, SAWāir alAmsāl. ${ }^{55}$

Itulah seluruh karya ilmiahnya yang kita ketahui dari berbagai data yang ada yang telah di tulis oleh az-Zamakhsyari, apabila kita mengamati karya-karyanya maka banyak di dapatkan tulisannya membahas tentang tata bahasa, karena semenjak mudanya az-Zamakhsyari senang terhadap ilmu lughah.

\section{Keutamaan jihad dan hijrah di jalan Allah dalam Tafsir al-Kasysyaf}

Pertama; QS.Al-Baqarah (2) : 218; “Sesungguhnya orang-orang yang beriman, orang-orang yang berhijrah dan berjihad di jalan Allah, mereka itu mengharapkan Rahmat Allah, dan Allah Maha Pengampun lagi Maha Penyayang." (QS.al-Baqarah,2: 218).

Az-Zamakhsyari menafsirkan ayat ini, yang disandarkan melalui periwayatan yaitu dari Ibnu Jarir, Tabrani, Ibnu Hatim, sedangkan al-Baihaqiy

${ }^{55} \mathrm{Ibid}, \mathrm{h} .51$ 
meriwayatkan dari Jundub bin Abdillah, berkata ayat ini turun pada sekelompok sahabat yang dikepalai oleh Abdullah bin Jahsy, mereka membunuh seorang laki-laki dari kelompok musyrik yang bernama alHudramiy. Lalu orang-orang mengira bahwasanya orang-orang yang berhijrah, beriman dan berjihad, mereka akan selamat dari dosa akan tetapi mereka tidak dapat ganjaran dari Allah. Lalu turunlah ayat "mereka itulah orang-orang yang mengharapkan Rahmat dari Allah". Diriwayatkan dari Qatadah, bahwasanya mereka itulah umat yang terpilih dari umat yang lain, kemudian Allah menjadikan mereka orang-orang yang selalu mengharapkan Rahmat dari Allah. ${ }^{56}$

Di dalam ayat 218 dengan ayat sebelumnya yaitu 216 dan 217, adanya keterkaitan yang membicarakan tentang masalah perang. Saudara-saudara mereka yang Islam-sesudah turunnya firman Allah, "mereka bertanya kepadamu tentang berperang dibulan Haram" (QS.2 : 217) - berkata, "Jika mereka tidak membuang bebannya maka tidak ada pahala bagi mereka." Maka Allah menurunkan firmannya diatas $(2: 218)$. Ungkapan ayat tersebut didasarkan keumuman lafaz bukan kekhususan sebab. Jadi berlaku universal. Setiap orang beriman sepanjang zaman dilarang murtad atau menampakkan sikap kufur penuh kebencian. Dalam Alquran dinyatakan, "Dan hatinya merasa tenang dengan keimanan". Adapun murtad dalam bentuk tindakan maka balasannya adalah dimasukkan ke Neraka, mereka kekal di dalamnya. Sebaliknya sabar, kokoh, jihad dan hijrah maka pelakunya "mengharap Rahmat Allah, dan Allah Maha Pengampun lagi Maha Penyayang".

Kedua; QS. An-Nisa (4) : 95; “Tidaklah sama antara mukmin yang duduk (tidak ikut berperang) yang tidak mempunyai udzur dengan orangorang yang berjihad dijalan Allah dengan harta mereka dan jiwanya. Allah melebihkan orang-orang yang berjihad dengan harta dan jiwanya atas orangorang yang duduk satu derajat. Kepada masing-masing mereka Allah menjanjikan pahala yang baik (surga) dan Allah melebihkan orang-orang yang berjihad atas orang yang duduk dengan pahala yang besar." (QS.AnNisa', $4: 95)$.

Az-Zamakhsyari menjelaskan ayat ini tentang keutamaan orang-orang mukmin yang berjihad fisabilillāh dengan harta dan jiwanya, dibandingkan dengan orang mukmin yang hanya duduk saja padahal tidak ada halangan

${ }^{56}$ Az-Zamakhsyari, al-Kasysyāf `an Haqā `iqit-Tanzil wa 'Uyūnil-Aqāwil fi Wujūhit-Ta'wil Jilid I (Misr: al-Bāb al-Halabi, 1966) h. 357 
untuk berjihad. Adapun kalimat "Ulil ad-Dharari". Bacaan kalimat tersebut ada tiga macam : lafal "ghairu" pertama yaitu marfu' artinya sifat bagi orangorang yang duduk, kedua manşub sebagai pengecualian dari kondisi dan keadaan mereka dan ketiga majrūr yaitu suatu sifat bagi orang-orang yang beriman. Kalimat "ad-Dhararu" artinya mereka yang dalam keadaan sakit atau lemah disebabkan karena buta atau sudah tua renta atau sebab-sebab lainnya. ${ }^{57}$

Diriwayatkan dari Zaid bin Tsabit, saya berada disamping Rasulullah SAW, Rasulullah bersabda: “Tidak akan sama antara orang mukmin yang duduk-duduk (tidak ikut berperang) yang tidak mempunyai użur dengan orang-orang mukmin yang berjihad di jalan Allah". Dari Ibnu Abbas menjelaskan maksud dari orang yang duduk-duduk yaitu pada perang Badar mereka tidak ikut, dan menurut muqatal sampai dengan perang Tabuk.

Kemudian dijelaskan pula, bahwasanya derajat orang mukmin yang berjihad di jalan Allah lebih tinggi tingkatannya daripada orang mukmin yang duduk (tidak ikut berperang) tanpa użur. Ayat ini diteruskan dengan firman Allah "Sesungguhnya Allah melebihkan orang-orang yang berjihad". ${ }^{5}$ Adapun lafal "wa kullan" bermakna setiap kelompok dari orang-orang yang duduk (tidak ikut berperang) disebabkan ada użur dan orang-orang yang berjihad.

Dua kelompok ini, jika sama dalam keimanan dan keikhlasannya dalam melaksanakan sesuatu, maka Allah menjanjikan kepada mereka balasan kebaikan yang berupa surga. Dijelaskan pula bahwasanya orang yang menunaikan kewajiban-kewajibannya, berbuat taat, lalu berjihad dengan jiwa dan hartanya dijalan Allah, maka Allah melebihkan orang-orang yang berjihad dengan pahala yang besar berupa balasan mereka yaitu pengampunan, kasih sayang dari Allah SWT. ${ }^{59}$

Ketiga; QS. Al-Maidah (5): 54; “Hai orang-orang yang beriman, barangsiapa diantara kamu yang murtad dari agamanya, maka kelak Allah akan mendatangkan suatu kaum yang Allah mencintai mereka dan mereka pun mencintai-Nya, yang bersikap lemah lembut terhadap orang yang mukmin, yang bersikap keras terhadap orang-orang kafir, yang berjihad di

57 Ibid, h. 555

${ }^{58}$ Ibid

${ }^{59}$ Ibid, h. 556 
jalan Allah, dan yang tidak takut kepada celaan orang yang suka mencela. Itulah karunia Allah diberikannya kepada siapa yang di kehendaki-Nya, dan Allah Maha luas (pemberian-Nya) lagi Maha Mengetahui." (QS. Al-Maidah, 5: 54).

Az-Zamakhsyari menafsirkan, sesungguhnya agama Islam akan tegak dari orang-orang mukmin yang benar keimanannya. Adapun orang-orang yang murtad dari agama Allah karena dia tidak menghayati akan keimanannya kepada Allah dalam hati-hati mereka, maka Allah mendatangkan para pengganti mereka yang benar-benar menghayati keimananya kepada Allah, lalu mereka merasa mencintai Allah dan Allah pun mencintai mereka. Yang demikian itu sifat dari orang mukmin yang benar. ${ }^{60}$

Adapun lafal "ażillatin" jamak dari lafal "żalilun" dan lafal "żalulun" jamak dari lafak "żallun", maka bermakna orang yang beriman untuk bersikap lemah lembut terhadap orang-orang mukmin, maka dalam lafal tersebut mempunyai dua kandungan : pertama sebagai rasa tanggung jawab untuk bersikap baik dan lemah lembut serta bersikap tawadhu'(rendah hati). Yang kedua sesungguhnya mereka (orang mukmin) atas kemuliannya dan derajatnya yang tinggi serta diberikan kelebihan oleh Allah kepada mereka suatu keberhasilan dan sebagainya.

Bacaan "ażillatin dan a izzatin" dengan dimanşubkan atas hāl. Sebagaimana Allah berfirman : "bersikap lemah lembut kepada orang mukmin dan bersikap tegas kepada orang kafir harbi". Selanjutnya ayat tersebut diteruskan dengan "dan janganlah kamu takut kepada celaan orang yang suka mencela". Ayat ini meliputi lafal "al-wāwwu" dengan "hāl" maksudnya sesungguhnya orangorang yang berjihad di jalan Allah, mereka itulah dalam keadaan yang benarbenar berjihad. Tidak seperti orang-orang munafik, sesungguhnya mereka golongan orang-orang yang tercela, mereka itu apabila keluar untuk berperang dalam barisan orang-orang mukmin, mereka takut dicela oleh orang-orang Yahudi, maka mereka tidak mengerjakan sesuatu dalam peperangan, sebagaimana yang kita ketahui bagaimana sifat orang-orang munafik.

Adapun orang mukmin yang berjihad di jalan Allah mereka itulah yang hanya semata-mata karena Allah dan mereka itu tidak takut kepada celaan orang-orang yang suka mencela. Dan sandaran bagi orang-orang yang

${ }^{60} \mathrm{Ibid}, \mathrm{h} .622$ 


\section{Agus Handoko}

beriman yaitu memiliki sifat dari mereka untuk selalu berjihad di jalan Allah, dan sesungguhnya mereka pulalah yang menjadi benteng yang kuat dalam agamanya. Apabila agama mensyari'atkan untuk melaksanakan perintahperintah agama mereka melaksanakannya yaitu dengan melakukan kebaikan dan meninggalkan perbuatan yang jelek. Maka Allah memberikan kepada mereka kelebihan dan keutamaan yang sangat banyak dan tinggi. ${ }^{61}$

Keempat, QS. Al-Anfal (8) : 72;

"Sesungguhnya orang-orang yang beriman dan berhijrah, serta berjihad dengan harta dan jiwanya pada jalan Allah dan orang-orang yang memberikan tempat kediaman dan pertolongan (kepada orang-orang Muhajirin), mereka itu satu sama lain saling melindungi. Dan terhadap orang yang beriman, tetapi belum berhijrah maka tidak ada kewajiban sedikitpun atasmu melindungi mereka, sebelum mereka berhijrah. (Akan tetapi) jika mereka meminta pertolongan kepadamu dalam (urusan pembelaan) agama, maka kamu wajib memberikan pertolongan kecuali terhadap kaum yang telah ada perjanjian antara kamu dengan mereka. Dan Allah Maha Melihat apa yang kamu kerjakan." (QS. Al-Anfal, $8: 72$ )

Az-Zamakhsyari menafsirkan ayat ini diawali dengan lafal "Hājaru" yaitu orang-orang yang berhijrah karena cintanya kepada Allah dan RasulNya, mereka terdiri dari berbagai macam suku. Adapun golongan "Anshār" yaitu orang-orang yang memberikan tempat berlindung sampai dengan memberikan harta mereka dan menolong mereka (Muhājirin) dari musuhmusuh mereka. ${ }^{62}$

Kemudian az-Zamakhsyari meneruskan penafsiran dengan ayat "Ba'dhukum auliyā'u ba'dhin" yaitu mereka (Muhājirin dan Anshār) saling melindungi satu sama lain dan saling memiliki dalam hak pewarisan. Adapun kaum (Muhājirin dan Anshār) mereka saling waris-mewarisi tanpa adanya hubungan kekerabatan (sanak saudara) sampai Allah menasakh ayat tersebut dengan ayat yang lain berbunyi "Wa ulul Arhāmi ba'dhukum aulā bi ba'dhin" artinya "Dan bagi orang-orang yang mempunyai hubungan darah saja, yang dapat waris-mewarisi antara satu dengan lainnya."

Adapun bacaan lafal "Min Walāyatihim" dengan di fathah dan kasrah yakni mengandung makna mereka mempunyai hak perwalian di dalam harta warisan. Selanjutnya diteruskan dengan ayat "Fa'alaikumun Naşru" yaitu

\footnotetext{
${ }^{61} \mathrm{Ibid}, \mathrm{h} .623$

${ }^{62}$ Ibid, Jilid II h. 170
} 
diwajibkan bagi kamu sekalian untuk menolong saudaramu dari kejaran kaum musyrikin kecuali terhadap golongan yang telah membuat perjanjian, karena Islam tidak memperbolehkan pengingkaran janji dan pengkhianatan. ${ }^{63}$

Kelima, QS. Al-Anfal (8) : 74; “Dan orang-orang yang beriman dan berhijrah serta berjihad pada jalan Allah, dan orang-orang yang memberi tempat kediaman dan memberi pertolongan (kepada Muhajirin), mereka itulah orang yang benar-benar beriman. Mereka memperoleh ampunan dan rizki (nikmat) yang mulia." (QS. Al-Anfal, $8: 74$ )

Az-Zamakhsyari menjelaskan bahwa orang-orang mukmin yang berhijrah, berjihad di jalan Allah dan orang-orang yang memberi tempat kediaman dan pertolongan (kaum Anshār) sesungguhnya mereka itulah yang dapat dipercaya atas keimanannya kepada Allah sampai mereka rela meninggalkan sanak saudaranya dan tanah kelahirannya serta membelanjakan hartanya untuk tegaknya agama Islam. ${ }^{64}$ Lebih lanjut azZamakhsyari menjelaskan sesungguhnya ayat ini menerangkan tentang pujian atas mereka dan kesaksian bagi mereka atas keimanannya kepada Allah ditempat mereka berjanji (tempat yang mulia).

Keenam, QS. Al-Anfal (8) : 75; "Dan orang-orang yang beriman sesudah itu, kemudian berhijrah dan berjihad bersamamu, maka orang-orang itu termasuk golonganmu (juga). Orang-orang yang mempunyai hubungan kerabat itu sebagiannya lebih berhak terhadap sesamanya (dari pada yang bukan kerabat) di dalam kitab Allah. Sesungguhnya Allah Maha Mengetahui segala sesuatu." (QS. Al-Anfal, 8 : 75).

Az-Zamakhsyari menafsirkan ayat ini, terhadap orang mukmin yang berhijrah, berjihad dan kaum Anshār, mereka mempunyai kedudukan yang lebih utama dibandingkan gologan yang lain. Namun dalam hak pewarisan antara satu dengan yang lainnya yaitu hanya dengan kerabatnya saja (sanak saudara) yang dekat, bukan dengan Muhäjirin dan Anshär, karena ayat yang menerangkan tentang adanya hak waris antara Muhäjirin dan Anshār telah terhapus oleh ayat selanjutnya yang menerangkan tentang hak waris yang hanya dimiliki oleh kerabat terdekat yang masih ada ikatan keluarga. ${ }^{65}$

$$
\begin{aligned}
& { }^{63} \mathrm{Ibid} \\
& { }^{64} \mathrm{Ibid}, \mathrm{h} .170 \\
& { }^{65} \mathrm{Ibid}
\end{aligned}
$$


Ketujuh, QS. At-Taubah (9) : 20; “Orang-orang yang beriman dan berhijrah serta berjihad di jalan Allah dengan harta benda atau diri mereka, adalah lebih tinggi derajatnya disisi Allah; dan itulah orang-orang yang mendapatkan kemenangan." (QS. At-Taubah, $9: 20)$.

Az-Zamakhsyari menafsirkan ada dua golongan yang tinggi derajatnya disisi Allah; mereka dari orang-orang beriman dan berjihad di jalan Allah yang memberikan minuman kepada orang-orang yang mengerjakan haji dan mereka yang mengurus Masjidil Harām. azZamakhsyari meneruskan tafsirannya dengan ayat "Ulāika Humul Fāizun" mereka itulah orang-orang yang mendapatkan kemenangan bukan dari kalangan orang-orang kafir. Diriwayatkan dari Ibnu Abbas ra. Yang termasuk golongan yang mendapatkan kemenangan adalah orang-orang yang khusus berhijrah mengikuti Rasulullah SAW. ${ }^{66}$

Kedelapan, QS. at-Taubah (9) : 88; “Tetapi Rasul dan orang-orang yang beriman bersama dia, mereka berjihad dengan harta dan diri mereka. Dan mereka itulah orang-orang yang memperoleh kebaikan; dan mereka itulah (pula) orang-orang yang beruntung." (QS. At-Taubah, 9: 88)

Az-Zamakhsyari menafsirkan ayat ini dengan mengungkapkan bahwasanya orang-orang yang berdiri bersama Rasulullah untuk berperang, mereka itulah orang-orang yang lebih baik dari orang-orang yang tidak ikut berperang dan niat mereka (ikut berperang) benar-benar ikhlas dan yakin akan kebenaran serta mereka akan merasakan manfa'atnya dikemudian hari. ${ }^{67}$

\section{Sasaran jihad kaum muslimin}

a. QS. at-Taubah (9): 73

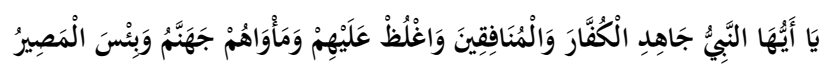

"Hai Nabi, berjihadlah (melawan) orang-orang kafir dan orang-orang munafik itu, dan bersikap keraslah kepada mereka, tempat mereka adalah neraka Jahanam. Dan itulah tempat kembali yang seburuk-buruknya." (QS. At-Taubah, 9:73)

Az-Zamakhsyari memulai penafsirannya pada ayat ini dengan lafal "Jāhidil Kuffāra" mempunyai makna berperang dengan orang-orang kafir

\footnotetext{
${ }^{66}$ Az-Zamakhsyari,.......... jilid II h. 180

${ }^{67}$ Ibid
} 
harbi dengan menggunakan kekuatan yang berupa persenjataan dalam menghadapi mereka. Kemudian dilanjutkan dengan lafal "Wal Munāfiqin" tegasnya melawan orang-orang munafik dengan memberikan hujjah atau adu argumentasi terhadap apa yang mereka (orang munafik) katakan. ${ }^{68}$ Bersikap keraslah kepada mereka dalam menghadapinya dan janganlah kamu menyayanginya karena bagaimanapun juga mereka (kafir harbi dan munafik) merusak dan mengacaukan aqidah umat Islam.

Diriwayatkan dari Ibnu Mas'ud, bahwasanya jihad harus dilakukan; jika jihad tidak mampu dengan kekuatan, maka dengan lisannya, apabila tidak sanggup juga maka dengan menampakkan kebencian dihadapannya, apabila tidak mampu melakukannya maka dengan hati. Ini merupakan suatu bentuk ketidak senangan dan kemarahan umat Islam kepadanya.

Diriwayatkan dari Hasan : bahwa jihad dengan orang-orang munafik adalah menegakkan peraturan-peraturan islam kepadanya, serta memberikan batasan-batasan jika mereka akan menggunakan kesempatan untuk menghasut umat Islam dengan alasan yang mereka buat-buat.

b. QS. Al-Haji (22) : 78

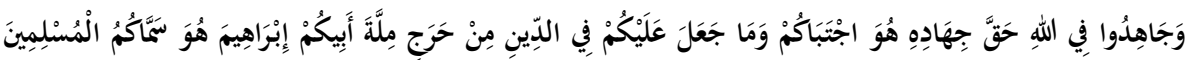

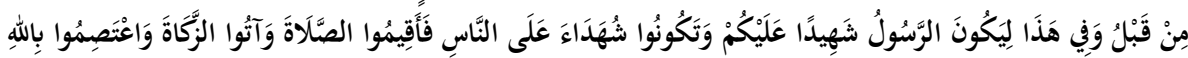

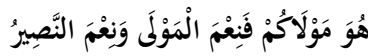

"Dan berjihadlah kamu dijalan Allah dengan jihad yang sebenar-benarnya. Dia telah memilih kamu dan Dia sekali-kali tidak menjadikan untuk kamu dalam agama suatu kesempitan. (Ikutilah) agama orang tuamu Ibrahim. Dia (Allah) telah menamai kamu sekalian orang-orang muslim dari dahulu, dan (begitu pula) dalam (Alquran) ini, supaya Rasul itu menjadi saksi atas segenap manusia, maka dirikanlah sembahyang, tunaikanlah zakat dan berpeganglah kamu pada tali Allah. Dia adalah Pelindungmu, maka Dialah sebaik-baik Penolong." (QS. Al-Hajj, 22 : 78)

Az-Zamakhsyari menjelaskan ayat ini dengan memulai lafal "Wajāhidu" yang bermakna perintah untuk berperang dan juga perintah melawan hawa nafsu dan hal ini merupakan jihad yang sangat besar. ${ }^{69}$ Dari Nabi SAW, sesungguhnya beliau telah pulang dari berbagai peperangan, lalu

\footnotetext{
${ }^{68}$ Ibid h. 202

${ }^{69} \mathrm{Ibid}$, Jilid III h. 23
} 


\section{Agus Handoko}

beliau bersabda: "Kita telah usai dari jihad yang kecil (perang) dan kita akan menghadapi jihad yang lebih besar (melawan hawa nafsu)70". Jihad hanya sematamata karena Allah yang harus dilaksanakannya dengan sungguh-sumgguh.

\section{c. QS. Al-Furqan (25) : 52}

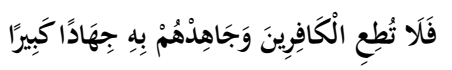

"Maka janganlah kamu mengikuti orang-orang kafir, dan berjihadlah terhadap mereka dengan Alquran dengan jihad yang besar." (QS. Al-Furqan, $25: 52)$

Az-Zamakhsyari menafsirkan ayat "Falā Tuthi'il Käfirīn" tegasnya orang-orang kafir harbi menginginkan orang-orang mukmin supaya mengikuti apa yang mereka lakukan. Adapun keinginan mereka (orang-orang kafir harbi) kepada kaum mukmin supaya mereka tidak lagi ta'at kepada perintah agama yang sudah termaktub dalam Alquran. Lalu Allah SWT. menegaskan "Janganlah ikuti mereka". Dan sesungguhnya orang-orang kafir harbi itu selalu meremehkan dan menghina perkara-perkara agama Islam dan mengajak untuk tidak ta' at kepada perintah agama. ${ }^{71}$

Untuk itu Rasulullah SAW menyerukan kepada para mujāhid untuk berjihad melawan orang-orang kafir harbi dengan mengeluarkan seluruh kemampuan yang ada dalam diri para mujāhid, disebabkan orang-orang kafir harbi telah menghina agama Islam.

\section{d. QS. Al-Hujurat (49): 15}

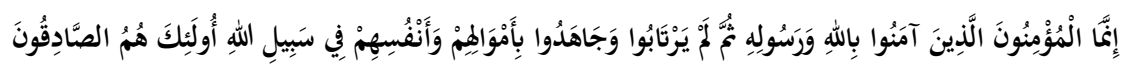

"Sesungguhnya orang-orang yang beriman hanyalah orang-orang yang beriman kepada Allah dan Rasul-Nya kemudian mereka tidak ragu-ragu dan mereka berjihad dengan harta dan jiwa mereka pada jalan Allah. Mereka itulah orang-orang yang benar." (QS. Al-Hujurat, 49 : 15)

Az-Zamakhsyari menjelaskan lafal "Wajāhadu" yaitu himbauan jihad yang objeknya adalah bisa melawan musuh dalam peperangan, melawan

70 Jami' al-'Ulum wa al-Hikam, Ibnu Rajab al-Hanbali, ( Dar al-Ma' rifah, Beirut ) 1408 H, h.. 196

${ }^{71}$ Az-Zamakhsyari...., h.. 66 
godaan syetan atau melawan hawa nafsu yang menyuruh kepada kejelekan. ${ }^{72}$ Jihad seperti ini harus dilaksanakan dengan sungguh-sungguh.

Adapun jihad dengan jiwa raga adalah berperang dan juga bisa berupa melaksanakan segala aktifitas ibadah dan juga bisa berupa mengeluarkan sebagian harta (zakāt) atas seluruh yang berkaitan dengan harta kekayaan, sebagaimana yang telah dilakukan oleh Sahabat Nabi SAW yaitu Usman bin 'Affan ra. Perbuatan tersebut hanya semata-mata karena Allah SWT.

Kemudian ayat ini dengan "Ulāika Humus Şādiqun" yaitu orang yang benar-benar menyakini adanya Allah dan mereka tidak akan mendustakan kebenaran tersebut dan dengan sungguh-sungguh mereka mengimani-Nya.

e. QS. At-Tahrim (66): 9

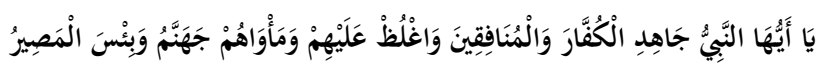

"Hai Nabi, perangilah orang-orang kafir dan orang-orang munafik dan bersikap keraslah terhadap mereka. Tempat mereka adalah neraka Jahanam dan itu adalah seburuk-buruk tempat kembali." (QS.At-Tahrim, 66 :9)

Az-Zamakhsyari memulai penafsirannya dengan lafal "Jāhidil Kuffär" yakni jihad dengan orang kafir harbi berupa perang dengan senjata. Serta dilanjutkan dengan lafal "Wal Munäfikin" yakni perang melawan orang munafik adalah dengan adu argumentasi (hujjah). Karena bagaimanapun juga kedua golongan tersebut merupakan musuh orang-orang beriman yang harus dilawan. ${ }^{73}$

Menurut Qatādah, jihad melawan orang-orang munafik harus dengan menegakkan peraturan-peraturan yang keras kepada mereka. Menurut riwayat yang lain dikatakan, bahwa melawan orang-orang munafik harus dengan mengungkapkan kejelekan-kejelekan mereka yang telah berkhianat kepada agama. Oleh karena itu pada ayat ini pula, musuh yang paling berbahaya dan kita bersikap keras pada keduanya yaitu dari kalangan kaum kafir harbi dan munafik.

\section{Balasan bagi orang yang berjihad dan yang tidak mau berjihad}

a. QS. Ali-'Imran (3): 142

\footnotetext{
${ }^{72} \mathrm{Ibid}$, h. 571

${ }^{73} \mathrm{Ibid}, \mathrm{h} .570$
} 


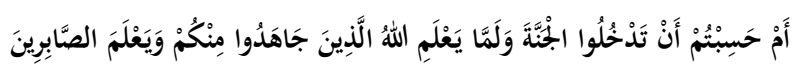

"Apakah kamu mengira bahwa kamu akan masuk surga padahal belum nyata bagi Allah orang-orang yang berjihad diantaramu dan belum nyata orangorang yang bersabar." (QS.Ali-'Imran, $3: 142$ )

Az-Zamakhsyari menafsirkan pada ayat ini, dengan memulai kalimat "am" yang terpisah pada kalimat "Hamzah" di dalamnya mempunyai makna orang-orang yang ingkar dan pembangkang. Kemudian Zamakhsyari meneruskan dengan kalimat "padahal belum nyata bagi Allah". Karena pada kalimat ini menerangkan tentang pengetahuan yang berkaitan dengan kemampuan manusia untuk mengira-ngira baik atau tidak pekerjaan yang dilakukannya.

Adapun kalimat "lammā" mempunyai makna "belum nyata" kecuali terdapat di dalamnya suatu pelajaran atau hikmah dari setiap kejadian. Lafal tersebut menunjukkan belum adanya jihad pada waktu lalu dan dinantikan adanya jihad dimasa yang akan datang. ${ }^{74}$ Ayat ini sangat berkaitan sekali dari ayat 139-143, karena di dalam ayat tersebut mengisahkan terjadinya peperangan antara orang musyrik dan orang mukmin pada perang Uhud.

Pada ayat-ayat sebelumnya Allah memberitahukan kepada orangorang beriman, tidak sepantasnya mereka merasa lemah atau berduka cita serta bersedih dalam menghadapi ujian-ujian yang mereka alami dalam peperangan, karena hal itu semua terdapat petunjuk dan bimbingan yang melatih orang-orang beriman kepada sifat-sifat yang terpuji. Az-Zamakhsyari menjelaskan pula bahwa orang Arab membaca kalimat "Walammā ya' lamillähu" dengan memfathahkan "mim" seakan-akan Allah berfirman "Apakah kalian mengira akan masuk surga tanpa perjuangan dan kesabaran?". Dikatakan pula dengan menggunakan "Nun al-Khafifah" menjadi "Walamma ya'lamna". ${ }^{75}$

Kata kerja "Ya'lamna" adalah manşub, dengan menyembunyikan huruf "an" dengan "wawu", yang berfungsi penggabungan. Diriwayatkan dari Abdul Waris dan dari Abu Umar, kalimat "Waya'lamu", maka redaksi ayat itu menjadi "Apakah kamu mengira akan masuk surga, padahal belum nyata dari kalian dalam melakukan jihad dan kesabaran". Jadi menurut Zamakhsyari bahwasanya meninggal dunia dalam keadaan syahid tidak akan didapat bagi orang yang

\footnotetext{
${ }^{74}$ Ibid, h. 466

${ }^{75}$ Ibid, h. 467
} 
hanya berangan-angan (tidak produktif) akan tetapi mati syahid akan didapatkan bagi orang-orang beriman dengan selalu berbuat kebaikan secara individu maupun masyarakat luas.

Sesungguhnya syahadat dengan ucapan lisan saja tidak cukup, tidak masuk surga, tidak selamat dari neraka, tidak menghimpun pahala, dan tidak pula meringankan siksa. Sesungguhnya syahādat harus disertai amal dan amal dalam bentuknya yang tertinggi dan paling berat adalah jihad fisabililläh dengan sungguh-sungguh dan sabar.

b. QS.At-Taubah (9): 16

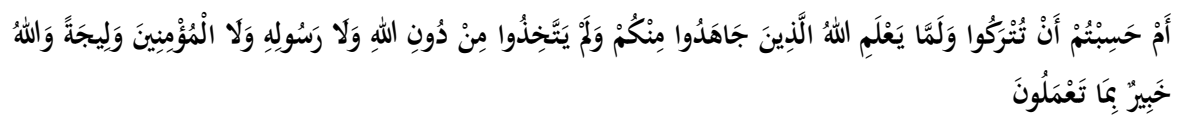

"Apakah kamu mengira bahwa kamu akan dibiarkan (begitu saja), sedangkan Allah belum mengetahui (dalam kenyataan) orang-orang yang berjihad diantara kamu dan tidak mengambil menjadi teman yang setia selain Allah, Rasul-Nya dan orang-orang yang beriman. Dan Allah Maha Mengetahui apa yang kamu kerjakan." (QS. At-Taubah, 9: 16)

Ayat ini sangat berkaitan dengan ayat sebelumnya yaitu ayat 13-16 yang menjelaskan bahwasanya setelah Allah SWT menyatakan tidak berkenan serta membebaskan Rasul-Nya dari orang-orang musyrik, dan berbicara tentang pelanggaran janji mereka dan pengkhianatan mereka terhadap orangorang Islam untuk memerangi mereka setelah "mereka melanggar janji" dan mengingatkan mereka bagaimana "mereka telah berkemauan keras untuk mengusir Rasulullah" dan lebih dahulu memerangi orang-orang Islam, padahal orang-orang Islam tidak memerangi mereka. Allah juga menyatakan bahwa orang-orang Islam berada dipihak yang benar dan didukung oleh pertolongan Allah SWT.

Dari hal tersebut dikemukakan suatu pertanyaan rabbani yang membekas bagi setiap perasaan umat Islam; dengan jawabannya yang bersifat rabbani juga, yakni "Apakah kamu semua takut kepada mereka? padahal Allah-lah yang berhak untuk kamu takuti, jika kamu adalah orang-orang yang beriman". Tegasnya seseorang tidak boleh takut kepada siapapun kecuali hanya kepada Allah SWT semata. ${ }^{76}$

${ }^{76} \mathrm{Ibid}, \mathrm{h} .178$ 
Orang-orang yang setelah diberikan pertanyaan tersebut lantas tetap tidak mau berjihad ; baik karena takut terbunuh maupun bersifat pengecut, tentu tidak dapat dianggap sebagai orang yang beriman. Sebab perang orangorang Islam terhadap orang-orang kafir harbi, merupakan adzab untuk mereka, serta merupakan pertolongan dan pelipur hati orang-orang yang beriman.

Kemudian menurut Zamakhsyari lafal "am" dalam kalimat serupa itu mengandung maksud permintaan jawaban yang mempunyai makna sesungguhnya kamu sekalian janganlah meninggalkan atas segala sesuatu yang telah kamu lakukan untuk berjihad di jalan Allah sehingga kamu ikhlas melaksanakannya karena Allah semata dan janganlah kamu mengambil teman selain yang ikhlas karena Allah SWT.

Adapun lafal "lammā" (menunggu), dan Allah telah memberikan petunjuk bagi orang-orang yang jelas mengharapkan-Nya. Az-Zamakhsyari meneruskan tafsirannya pada ayat "Walam Yattakhizu" ma'thuf bagi orangorang yang berjihad, dalam menjalin suatu ikatan persahabatan. Ayat tersebut diteruskan, "dan sedang Allah belum mengetahui (dalam kenyataan) orang-orang yang berjihad diantara kamu dan orang-orang yang mukhlis tidak mengambil menjadi teman yang setia selain Allah". Yang dimaksud dengan lafal "Nafsul 'Ilmu" artinya "Nafsul Ma'lum".77

\section{c. QS. At-Taubah (9) : 24}

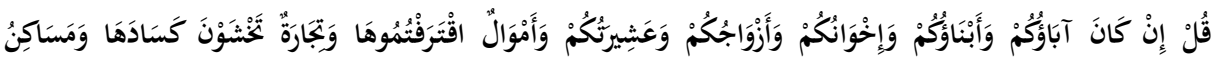

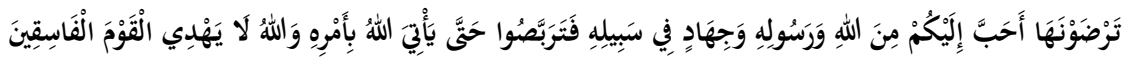

"Katakanlah: "Jika bapak-bapak, anak-anak, saudara-saudara, istri-istri, kaum keluargamu, harta kekayaan yang kamu usahakan, perniagaan yang kamu hawatir kerugiannya, dan rumah-rumah tempat tinggal yang kamu sukai, adalah yang lebih kamu cintai daripada Allah dan Rasul-Nya dan dari berjihad dijalan-Nya, maka tunggulah sampai Allah mendatangkan keputusan-Nya. Dan Allah tidak memberi Petunjuk kepada orang-orang yang fasik." (QS. At-Taubah, 9: 24)

Sesungguhnya aqidah Islam menuntut keikhlasan hati dan kesucian jiwa orang-orang yang memeluknya, guna menyakini tanpa sikap mencampurnya dengan hal lain baik keluarga, anak dan saudara.

77 Ibid 
Lalu az-Zamakhsyari menafsirkan ayat "Fatarabbasū hattā ya' tiyallāhu bi amrihi" yang bermakna janji Allah kepada mereka (orang-orang fasik) yang lebih mencintai keluarga dan harta mereka, dari pada kepada Allah RasulNya serta berjihad di Jalan-Nya, maka tunggulah sampai Allah mendatangkan keputusan-Nya. Diriwayatkan dari Ibnu Abbas, ayat ini turun ketika "Fathu Mekkah" dan diriwayatkan dari Hasan, bahwasanya keputusan Allah adalah suatu hukuman yang datangnya secara cepat atau bisa juga secara lambat. Ayat ini juga sebagai ayat peringatan Allah yang keras, sebagaimana yang diketahui dari ayat-ayat sebelumnya. ${ }^{78}$

\section{d. QS. At-Taubah (9) : 41}

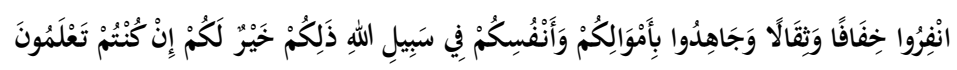

"Berangkatlah kamu baik dalam keadaan merasa ringan atau merasa berat, dan berjihadlah dengan harta dan dirimu di jalan Allah. Yang demikian itu adalah lebih baik bagimu jika kamu mengetahui." (QS. At-Taubah, 9:41)

Ayat ini berkaitan dengan ayat sebelumnya. Ayat tersebut turun ketika Rasulullah SAW mengajak kaumnya untuk ikut dalam perang Tabuk menghadapi tentara Romawi yang telah berkumpul di perbatasan Jazirah Arab. ${ }^{79}$ Saat itu sedang musim panas, tanaman mulai berbuah, dan umat Islam lebih suka tetap tinggal di Madinah. Mereka merasa berat untuk berangkat ikut bersama Rasulullah.

Az-Zamakhsyari menjelaskan ayat ini, yaitu dengan seruan Allah untuk ikut bersama Rasul dalam berperang dengan penegasan ayat "Infir $\bar{u}$ Khifäfan wa Tsiqalan". Lafal khifaf adalah bentuk jamak dari khafif (ringan) dan śiqāl adalah jamak dari śaqil (susah). Ringan dan susah ini menyangkut masalah tubuh (jasmani) beserta sifat-sifatnya, yakni sehat maupum sakit, kurus maupun gemuk, muda maupun tua, semangat maupun malas, dan diwaktu luang maupun sempit.

\section{d. QS. At-Taubah (9) : 81}

78 Ibid h. 181

${ }^{79}$ Syāhid al-Islam al-Uastadz as-Sayyid Quțb, Tafsir fi Zhilal al-Qur'an Jilid X (Beirut: Dar al-Fikr, tth) h. 165 


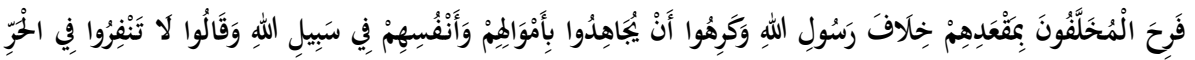

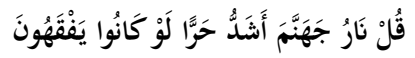

“Orang-orang yang ditinggalkan (tidak ikut berperang) itu, merasa gembira dengan tinggalnya mereka dibelakang Rasulullah SAW dan mereka tidak suka berjihad dengan harta dan jiwa mereka pada jalan Allah, dan mereka berkata : "Janganlah kamu berangkat (pergi berperang) dalam panas terik ini". Katakanlah : Api neraka Jahanam itu lebih sangat panasnya", jikalau mereka ketahui." (QS. At-Taubah, 9: 81)

Az-Zamakhsyari menerangkan dalam ayat ini, bahwasanya Rasulullah sungguh sangat jelas kasih sayangnya dan sikap lembutnya kepada umatnya dan selalu mendoakan untuk mereka. Kemudian Zamakhsyari melanjutkan penafsirannya, adapun orang-orang yang izin kepada Rasulullah untuk tidak ikut berperang dalam perang Tabuk dan Rasulullah memberikan izin kepada mereka, lalu mereka tinggal di Madinah. Mereka itulah dari golongan orangorang munafik. Karena mereka itu memiliki sifat penghianat ketika berada dibelakang Rasulullah. ${ }^{80}$

Hal ini menyebabkan Allah SWT menegur sang Rasul, sambil menjelaskan bahwa; kalau beliau meninggalkan mereka dan urusan mereka, maka sungguh lebih utama dengan mengungkap orang yang benar diantara mereka daripada orang yang pendusta.

Adapun orang-orang yang berjihad dengan harta dan jiwa mereka, mereka itulah orang yang benar-benar beriman kepada Allah karena setiap ada panggilan untuk berjihad dijalan Allah, mereka selalu melaksanakannya tanpa menolak sedikitpun, sehingga hal ini menimbulkan kebencian dari kalangan munafik. ${ }^{81}$

Kemudian az-Zamakhsyari mengakhiri ayat ini “Qul Nāru Jahannama Asyaddu Nāra" disebabkan kebodohan dan ketidaktahuan orang-orang munafik akan perintah jihad, maka Allah memerintahkan Nabi Muhammad SAW untuk memberitahukan kepada mereka, bahwasanya neraka Jahanam lebih panas ketimbang hari-hari dimedan perang yang disediakan bagi orangorang yang berdusta kepada Allah dan Rasul-Nya.

e. QS. At-Taubah (9): 86

${ }^{80}$ Ibid jilid II h. 205

${ }^{81}$ Ibid 


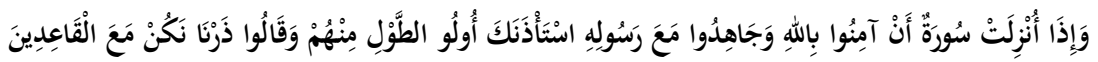

“Dan apabila diturunkan suatu surat (yang memerintahkan kepada orang munafik itu) : "Berimanlah kamu kepada Allah dan berjihadlah beserta RasulNya", niscaya orang-orang yang sanggup diantara mereka meminta izin kepadamu (untuk tidak berjihad) dan mereka berkata : "Biarkanlah kami berada bersama orang-orang yang duduk." (QS. At-Taubah, 9: 86)

Ayat tersebut kembali berbicara mengenai orang-orang yang ikut meminta izin untuk tidak ikut berjihad dijalan Allah, padahal mereka mempunyai keluasan harta dan kemampuan raga untuk berjihad. AzZamakhsyari menjelaskan ayat "wa iż̄ unzilat sūratun" yaitu sebagaimana yang diturunkan Allah berupa Alquran merupakan kitab untuk seluruh umat manusia.

Diriwayatkan pula, bahwa Alquran merupakan pedoman yang di dalamnya terdapat perintah untuk beriman kepada Allah dan berjihad dijalan-Nya. ${ }^{82}$ Adapun ayat "Ulut Thauli" adalah orang-orang yang mempunyai kemampuan dan waktu yang luang. Akhir dari ayat ini " $M a^{\prime} a l$ $Q \bar{a}$ 'idin" yaitu orang-orang yang beralasan untuk tidak ikut berperang dan mereka (orang munafik) menginginkan berada dibelakang Rasulullah. Jadi ayat ini menjelaskan gambaran yang buruk tentang orang-orang yang menolak berjihad, disebabkan mereka lebih suka tinggal dirumah tanpa aktivitas produktif.

\section{g. QS. Al-Ankabut (29): 6}

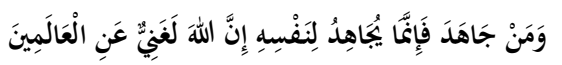

"Dan barang siapa yang berjihad, maka sesungguhnya jihadnya itu adalah untuk dirinya sendiri. Sesungguhnya Allah benar-benar Maha Kaya (tidak memerlukan sesuatu) dari semesta alam." (QS. Al-Ankabut, 29 : 6)

Az-Zamakhsyari menjelaskan lafal "Waman Jāhada" yaitu orang yang menahan diri dari apa-apa yang disenangi hawa nafsunya dan menjalankan sesuatu yang dibenci oleh hawa nafsunya. ${ }^{83}$ Karena pada dasarnya hal itu merupakan suatu manfa'at yang akan kembali kepada dirinya dan hal tersebut merupakan suatu Rahmat atau Kasih Sayang Allah kepada hambaNya.

\footnotetext{
${ }^{82}$ Ibid h. 207

${ }^{83} \mathrm{Ibid}, \mathrm{h} .197$
} 
Adapun orang-orang muslim yang shaleh, jika mereka berbuat kejelekan dari sebagian apa yang telah dilakukannya, maka perbuatan yang jelek itu akan terhapus oleh perbuatan baiknya, dan Allah akan memberi ganjaran bagi mereka yang berbuat kebaikan.

Adapun orang-orang musyrik yang bertaubat lalu beriman kepada Allah serta mengerjakan perbuatan baik, maka Allah akan menghancurkan segala dosa-dosanya yang telah dilakukannya dimasa lalu, dan Allah memberikan ganjaran pahala bagi mereka yang telah masuk Islam dalam setiap perbuatannya.

h. QS. Al-Ankabut (29): 69

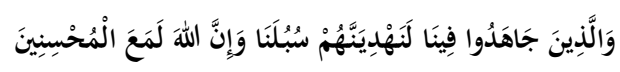

“Dan orang-orang yang berjihad untuk (mencari keridhaan) Kami, benarbenar akan kami tunjukkan kepada mereka jalan-jalan Kami. Dan sesungguhnya Allah benar-benar beserta orang-orang yang berbuat baik." (QS. Al-Ankabut, 29: 69)

Az-Zamakhsyari menjelaskan pada ayat ini yaitu bagi seorang mujāhid harus bersungguh-sungguh dalam menahan hawa nafsu amarah, dan melawan godaan syetan, dan musuh-musuh agama Islam. Kemudian Zamakhsyari melanjutkan dengan lafal "Fina" maksudnya hanya untuk mencari keridhaan Allah SWT semata dan dengan penuh keikhlasan. ${ }^{84}$ Maka Allah akan menambahkan suatu petunjuk kejalan yang baik serta pertolongan-Nya. Diriwayatkan dari Abu Sulaiman ad-Daraniy; bahwasanya orang yang berjihad akan mengetahui dari sesuatu yang tidak diketahuinya dengan petunjuk Allah SWT yang diberikan-Nya.

i. QS. Muhammad (47): 31

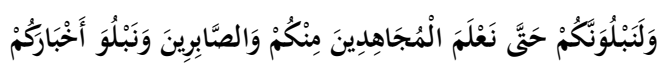

"Dan sesungguhnya Kami benar-benar akan menguji kamu agar Kami mengetahui orang-orang yang berjihad dan bersabar diantara kamu; dan agar Kami menyatakan (baik buruknya) hal ihwalmu." (QS. Muhammad, 47 : 31)

${ }^{84} \mathrm{Ibid}$, Jilid III h. 213 
Az-Zamakhsyari menafsirkan ayat ini, dengan penegasan Allah yaitu bahwasanya Kami (Allah) mengetahui orang yang sungguh-sungguh dalam melakukan perbuatan baik dan mereka yang bersabar. Maka bagi siapa yang berbuat baik, balasannya kebaikan pula dan yang berbuat kejelekan, maka balasannya kejelekan pula. ${ }^{85}$

j. QS. Ash-Shāf (61): 11

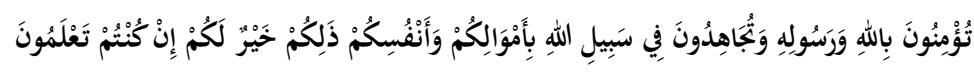

"(yaitu) kamu beriman kepada Allah dan Rasul-Nya dan berjihad dijalan Allah dengan harta dan jiwamu. Itulah yang lebih baik bagimu jika kamu mengetahuinya." (QS. Ash-Shaff, 61: 11)

Ayat ini sangat berkaitan dengan ayat sebelumnya dan sesudahnya. Az-Zamakhsyari menjelaskan lafal "Tu'minūna" yaitu kalimat "Isti naf" (permulaan). Seperti orang-orang yang beriman dari kalangan Sahabat Rasul SAW berkumpul dan berkata, "Andai saja kami mengetahui amal apa yang paling dicintai oleh Allah dan bagaimana kami bisa melaksanakannya". Lalu turunlah firman Allah, yang berbunyi : "Tu 'minūna" yang bermakna suatu perintah atas informasi yang diberitahukan oleh Allah. Diriwayatkan dari Ibnu Mas'ud bahwa lafal "Tu'minūna" mengandung makna beriman kepada Allah, Rasul-Nya dan berjihad dijalan-Nya. ${ }^{86}$

Setelah mereka mengerjakan perintah tersebut, maka jawaban dari Allah adalah Allah akan menghapus segala dosa-dosa mereka. Sesungguhnya iman dan jihad merupakan dua perkara yang harus dilakukan bagi orangorang yang beriman, karena kedua perkara tersebut yang paling baik bagimu diatas kecintaanmu kepada dirimu dan hartamu.

\section{Relevansi Penafsiran az-Zamakhsyari tentang Jihad pada Konteks Sekarang}

Jika direnungkan tentang penafsiran-penafsiran az-Zamakhsyari masalah jihad, setelah dijelaskan ayat perayat dalam Alquran, maka dapat kita analisa penjelasan az-Zamakhsyari yang disusun melalui kitab tafsirnya yang terkenal yaitu al-Kasysyāf ’an Haqäiqit-Tanzil wa 'Uyūnil-Aqāwil fi Wujūhit$T a^{\prime}$ wil sebagai berikut jihad dapat diklasifikasikan menjadi :

\footnotetext{
${ }^{85} \mathrm{Ibid}, \mathrm{h} .538$

${ }^{86}$ Ibid, Jilid IV h. 526-527
} 


\section{Agus Handoko}

1. Jihad melawan diri sendiri, berupa menahan diri dari godaan syetan dan hawa nafsunya yang mengajak kepada perbuatan yang dilarang oleh agama.

2. Jihad melawan orang-orang kafir harbi (yang memerangi kaum muslimin) berupa adu kekuatan dengan perang senjata sesuai aturan syar'i.

3. Jihad melawan orang-orang munafik berupa sikap yang tegas dengan adu argumentasi (hujjah).

Dari tiga kesimpulan tersebut, maka kita akan mengkorelasikan dengan keadaan dan pemahaman umat Islam tentang jihad yang terjadi pada saat sekarang.

Pada bagian pertama; Jihad melawan diri sendiri dari hawa nafsu, umat Islam jarang sekali memperhatikan masalah ini karena masih banyak kasus-kasus pidana yang dilakukan oleh umat Islam itu sendiri, contohnya penganiyaan, pencurian, pemerkosaan, korupsi dan perbuatan lainnya yang dilarang oleh agama yang terjadi dimana-mana. Ini akibat dari tidak mampunya seseorang dalam melawan hawa nafsunya, baik yang ada dalam dirinya maupun diluar dirinya.

Jihad (nafs) melawan hawa nafsu ini, merupakan pokok dari jihad dan juga merupakan jihad paling besar yang harus kita hadapi secara sungguhsungguh, sebagaimana yang telah disabdakan oleh Rasulullah kepada kaum muslimin setelah usai dari berbagai pertempuran. Oleh karena itu jihad nafs, bisa dilakukan oleh umat Islam melalui empat tingkatan:

Pertama, Melalui upaya pembekalan diri dengan ilmu-ilmu agama, sehingga ia mencintainya dan memahaminya dengan pemahaman yang benar.

Kedua, Melalui upaya pengamalan ilmu tersebut dalam kehidupan didunia ini.

Ketiga, Melalui upaya penyampaian dalam bentuk dakwah mengajak dan mengajar manusia dengan ilmu tersebut.

Keempat, Melalui upaya untuk tetap bersabar menghadapi segala resiko dan gangguan dalam menjalankan misi dakwahnya. ${ }^{87}$

${ }^{87}$ Ja'far Umar Thalib, Jihad fi Sabilillāh; Solusi Problematika Bangsa dan Negara Indonesia, dalam Majalah Salafiy Edisi XXXIV / 1421 H (Yogyakarta: Yayasan as-Sunnah, 2000) h.. 3 
Dari solusi yang disebutkan diatas, maka tampak jelas bahwasanya jihad melawan hawa nafsu dalam diri sendiri, lebih berat dan selalu dilupakan oleh umat Islam dari pada jihad-jihad yang lainnya. Dengan demikian mari kita mencoba untuk melakukan jihad secara totalitas pada diri kita.

Bagian yang kedua : Jihad melawan orang kafir harbi, jihad semacam ini selalu didengung-dengungkan oleh umat Islam yang radikal pada saat sekarang. Karena mereka melihat kearogansian orang-orang kafir harbi yang selalu mengganggu dan menginjak-injak martabat umat Islam dengan menggunakan dalih penegakkan Hak Asasi Manusia (HAM).

Padahal merekalah (orang kafir harbi) yang selalu melanggar HAM itu sendiri, seperti yang dialami oleh saudara-saudara muslim kita di Palestina, Afganistan dan negara-negara muslim lainnya yang menjadi korban kebiadaban mereka. Hukum asal jihad seperti ini adalah fardhu kifayah, artinya apabila telah dikerjakan oleh sejumlah yang cukup dari kaum muslimin, maka gugurlah dosa dari yang lainnya. Namun demikian bisa berubah menjadi fardhu 'ain manakala ada empat keadaan :

a. Apabila Imam (pimpinan) menyeru kaumnya untuk berjihad.

b. Apabila pasukan kaum muslimin telah berhadapan dengan pasukan kafir harbi.

c. Apabila musuh menyerang suatu negeri tersebut untuk memeranginya, maka harus membela diri.

d. Apabila dibutuhkan oleh kaum muslimin yang lain diluar daerah kita. ${ }^{88}$

Berkaitan dengan jihad melawan orang-orang kafir menurut Ja'far Umar Thalib perlu ada kejelasan, siapakah diantara orang-orang kafir yang wajib diperangi, menurut beliau dengan mengutip pendapat Imam Baihaqiy Asy-Syafi'iy, orang-orang kafir yang wajib diperangi dalam jihad adalah yang terang-terangan menyatakan permusuhan kepada kaum muslimin. Dalam kaitan ini menurut Ja'far, Islam telah mengajarkan untuk mengenal orang kafir mana yang harus diperangi. Sebab orang kafir menurut syari'at ada tiga macam :

88 Dzulqarnain, Ahkamul Jihad dalam Majalah Salafiy Edisi XXXIV / $1421 \mathrm{H}$ (Yogyakarta: Yayasan as-Sunnah, 2000) h. 15-17 


\section{Agus Handoko}

a. Kafir Harbi, yaitu kafir yang terang-terangan menyatakan permusuhan terhadap kaum muslimin, semata-mata karena keislamannya.

b. Kafir Dzimmi, yaitu orang non muslim yang menjadi warga negara muslimin dengan baik dan mentaati peraturan-peraturan yang berlaku serta menghargai kaum muslimin. Maka orang kafir dzimmi yang seperti ini mempunyai hak dan kewajiban yang sama dengan kaum muslimin.

c. Kafir Mu'ahad, yaitu non muslim dari negara lain yang mempunyai hubungan persahabatan dengan negara Islam, sehingga ketika dia masuk ke negara Islam, ia mendapat perlindungan dan jaminan untuk hidup tentram dan damai.

Dari ketiga macam orang kafir tersebut, hanya golongan kafir harbi yang wajib diperangi atau menjadi sasaran jihad kaum muslimin. ${ }^{89}$

Bagian ketiga yaitu, jihad melawan orang-orang munafik dengan sikap yang tegas terhadap mereka dan perlawanan adu argumentasi (hujjah), ketika mereka hendak menghasut umat muslimin.

Jihad seperti ini sangat jarang sekali diperhatikan oleh umat Islam, karena pada dasarnya mereka (orang-orang munafik) sangat bahaya ketika mereka melancarkan serangan-serangan dari dalam diri umat Islam dengan bentuk adu domba, menghasut, memfitnah antar sesama umat Islam dan juga membuat kebingungan terhadap ajaran yang diyakini dalam diri umat Islam. Sehingga tidak disadari bagi umat Islam telah diporak-porandakkan aqidah dan keimanan mereka.

Hal semacam ini, harus kita lawan dengan mengatakan yang benar (berhujjah) ketika mereka (orang munafik) berbicara yang sifatnya menghasut, membuat keragu-raguan dan mengajak kejalan yang sesat terhadap kaum muslimin. Karena bagaimanapun ciri orang munafik secara lahiriah tidak bisa diketahui secara jelas, sehingga sulit untuk membedakan orang Islam yang hakiki dengan orang Islam yang munafik. Untuk melakukan jihad melawan orang-orang munafik dapat dilakukan dalam empat tingkatan: Jihad dengan hati, Jihad dengan lisan, Jihad dengan harta, Jihad dengan jiwa raga. ${ }^{90}$

${ }^{89}$ Ja'far Umar Thalib, Panggilan Jihad Membela Muslimin Maluku, dalam Buletin Maluku Edisi 56 (Yogyakarta: Komis Dana Lasykar Jihad Korwil DIY, 2000) h. 2

${ }_{90}$ Op.Cit h. 3 
Setelah mengetahui tiga kesimpulan dari penafsiran az-Zamakhsyari dengan melihat realitas yang dihadapi saat sekarang, maka relevansi dari ketiga pengertian tersebut, bahwa pemahaman tentang jihad pada masa yang lalu (ketika az-Zamakhsyari menulis kitab al-Kasysyāf) sangat relevan ketika digunakan oleh kaum muslimin pada saat sekarang yang memberikan pengertian makna jihad yang dapat dilakukan dengan berbagai cara menurut pertimbangan alat maupun yang lainnya, selain itu agar umat Islam dapat kembali pada pemahaman sesungguhnya tentang jihad, bukan hanya jihādulkuffär saja yang menonjol namun jihad-jihad yang lainnya juga harus dilaksanakan.

Islam mengajarkan kepada umatnya, bahwasanya jihad bisa dilakukan setelah menyerukan kepada kebaikan dan memberitahukan akan kebenaran agama Islam, sebab prinsip ajaran Islam dalam dakwahnya tidak ada unsur yang sifatnya kekerasan dan juga paksaan. Oleh karena itu salah besar jika ada pemahaman bahwasanya Islam datang dengan kekerasan dan peperangan. Jihad yang terjadi akhir-akhir ini seperti kasus pertikaian antar agama di daerah Ambon maupun kota-kota lainnya di Indonesia bahkan bom bunuh diri, hal tersebut dikarenakan umat Islam masih menganggap, bahwa jihad hanya melawan orang-orang kafir harbi saja namun mereka tidak menyadari bahwasanya musuh umat Islam, adalah hawa nafsu yang tidak bisa dikendalikan merupakan musuh besar dalam diri manusia, yang harus dilawan bersama-sama.

\section{Penutup}

Dari uraian di atas melalui bab per bab yang telah penulis sajikan, maka dapat ditarik kesimpulan sebagai berikut:

Pertama, dalam istilah Alquran dan as-Sunnah, jihad artinya usaha yang sungguh-sungguh untuk mengatasi kepentingan pribadi guna kepentingan kebenaran yang menjadi pondasi dalam kepribadian seorang muslim. Usaha ini dilakukan dengan sepenuh jiwa dan harta, dengan membelanjakan waktu, umur dan sebagainya dalam bingkai kemaslahatan dengan memikul macam-macam kesukaran dan juga dengan mengahadapi pasukan yang menumpahkan darah. Untuk menghadapi pasukan musuh diperlukan waktu tertentu, tetapi untuk menghadapi diri pribadi bagi seorang mukmin ialah usaha seumur hidup, jihad diwaktu pagi dan sore. Jihad membentuk tiga kata kunci yang dapat mengantar manusia meraih predikat 
tertinggi sebagai manusia paripurna (insān kāmil) yaitu Jihad, Ijtihad dan Mujahadah.

Kedua, Jihad menurut az-Zamakhsyari dalam kitab tafsirnya alKasysyaf mempunyai makna yaitu sungguh-sungguh dalam memantapkan iman kepada Allah dengan berbagai cara yang diajarkan oleh agama. Serta dapat disimpulkan melalui tiga bagian:

a. Jihad melawan diri sendiri yaitu melawan hawa nafsu dan godaan syetan yang dapat menjerumuskan manusia kejalan maksiat dan sesat dari ingat Allah SWT, serta menahan diri dari sesuatu yang berdampak kerusakan individu maupun masyarakat.

b. Jihad melawan orang-orang kafir yaitu dengan melawan melalui kekuatan seluruh jiwa raga dan dengan perbekalan senjata untuk menghadapinya. Jihad semacam ini hanya diperuntukan kafir harbi.

c. Jihad melawan orang-orang munafik yaitu dengan sikap yang tegas terhadap mereka dan perlawanan adu argumentasi (hujjah), ketika mereka hendak membuat keragu-raguan tentang ajaran Islam dan propaganda yang negatif untuk menuju perpecahan dikalangan kaum muslimin.

Jihad yang semacam inilah, hanya semata-mata mencari ridha dari Allah SWT dan menegakkan agama Islam dimuka bumi ini, bukan karena sesuatu yang lain selain Allah SWT. Sungguh besar ganjaran dari Allah bagi mereka (orang mukmin) yang berjihad dengan harta dan jiwa raganya berupa Rahmat dan ampunan atas segala dosa-dosanya dan diberikan kedudukan yang tinggi didunia maupun diakherat kelak. Terhadap mereka (mukmin) yang tidak mau berjihad dan meninggalkannya, maka Allah akan menjadikan mereka golongan yang fasik.

Relevansi penafsiran az-Zamakhsyari dalam kitab al-Kasysyaf tentang jihad terhadap konteks sekarang, dapat dikatakan sangat sesuai bagi kaum muslimin yang akan melaksanakannya baik melalui lisannya, hartanya, maupun jiwa raganya secara proposional. Karena bagaimanapun juga jihad dengan bersungguh-sungguh menjalankan aktivitas yang produktif dalam memajukan agamanya lebih besar manfa'atnya dari pada hanya diam dan tidak melakukan sesuatu.

Dari kesimpulan yang telah penulis paparkan di atas, maka penulis akan memberikan saran-saran bagi pembaca dari hasil penelitian ini. 
Adapun saran-saran yang dapat diajukan menurut penulis diantaranya adalah; Pertama, dalam memahami dan melihat konsep jihad, janganlah umat Islam terlalu over action dalam melakukannya. Karena belum tentu jihad yang kita lakukan selama ini, menambah pemantapan iman kita kepada Allah SWT; Kedua, dalam dunia realitas ini, umat Islam dituntut untuk bersungguh-sungguh dalam memajukan agama dan negaranya baik dari segi ekonomi, sosial, budaya, teknologi. Itulah yang harus kita lakukan (jihad) dari berbagai segi tersebut; Ketiga, jangan dicampur adukkan antara jihad dengan aksi terorisme, karena bagaimanapun juga dua istilah tersebut tidak akan sama maknanya; Keempat, dalam penelitian ini, penulis masih belajar dalam memahami kitab tafsir al-Kasysyāf yang disusun oleh azZamakhsyari, oleh karena itu jika ada penulisan yang kurang tepat, maka harap dimaklumi dan penulis membuka masukan yang seluas-luasnya bagi mereka yang senang meneliti kitab-kitab tafsir.

\section{Pustaka Acuan}

Abdullah bin Muhammad bin Hamid. Ad-Dakwah ilal-Jihād fil-Qur'ān wasSunnah, diterjemahkan oleh Abu Ayyub al-Anshari dengan judul. Seruan Jihad Dalam Qur'an dan Sunnah. (Pustaka Haraki,1993)

Abdul Wahid, Sa'ad. Az-Zamakhsyari dan Tafsir Al-Kasysyaf ( Yogyakarta : IAIN SU-KA, 2000 )

Ali, Abdullah Yusuf. Alquran Terjemah dan Tafsirnya, terjemah Ali Audah. Jakarta : Pustaka Firdaus, 1993

Al-Audah, Salman. Jihad Sarana Menghilangkan Ghurbah Islam, terjemah Kathur Suhardi. Jakarta : Pustaka al-Kausar, 1993

Azzam, Shaheed Abdullah. Jihad Adab dan Hukumnya, terjemah Mahmood Malawi. Jakarta : Gema Insani Press, 1987

Al-Baqi, Muhammad Fuad Abd. Al-Mu'jam al-Mufahras li Alfāz al-Qur'ān. Kairo : Dar al-Fikr, 1981

Brill's, EJ. Firts Encyclopedia of Islam 1913-1956, volume VIII. Leiden, New York, Kobenharm, Kohn, 1987

Baiquni, N.A dkk. Indeks Alquran, Cara Mencari Ayat Alquran.(Surabaya : Arkola, 1996)

Chirzin, Muhammad. Jihad Dalam Alquran (Yogyakarta : Mitra Pustaka, 1997) 


\section{Agus Handoko}

Ad-Daqas, Kamil Salamah. Ayātul Jihād fìl Qur'ān al-Karīm. Kuwait : Dar alBayan, 1972

Ad-Dimasyqi, al-Hafiz Ibnu Kaşir. Tafsir Ibnu Kaşir, jilid II. Beirut : Dar al-Fikr, tth

Dzulqarnain. Ahkāmul Jihād, dalam Majalah Salafy, edisi XXXIV / $1421 \mathrm{H}$. Yogyakarta : Yayasan as-Sunnah, 2000

Fahruddin, HS. Ensiklopedia Alquran, jilid II. Jakarta : Rineka Cipta, 1992

Al-Hambali, Abul Fattah Abul Hay bin Ahmad. Syajaratuz Zahab fì Akhbāti Man Zahab. Beirut: Maktabah at-Tijārati li at-Tiba'āti wa an-Nasyri wa at-Tauzi, 1961

al-Hanbali, Ibnu Rajab Jami' al-'Ulum wa al-Hikam, (Dar al-Ma'rifah, Beirut) $1408 \mathrm{H}$

Ibnu Mandzur. Lisan al-'Arab al-Muhīth, juz I. Beirut : Dār al-Lisān al-'Arab, tth

Jibril, Abdurrahman Abu Muhammad. Potret Medan Jihad (Yogyakarta : Wihdah Press, 2000)

Al-Juwaini, Mustafa as-SAWi. Manhajuz Zamakhsyari fì Tafsīil Qur'āni wa Bayāni 'Ijāzih. Mesir : Dār al-Ma'ārif, 1968

Khathab, Mahmud Syait. Latar Belakang Kemenangan Islam, terjemah Kathur Suhardi. Solo : Pustaka Mantiq, 1992

Ma'luf, Abu luwis. Al-Munjīd fì al-Lughāh wa al-'Alam. Beirut : Dar al-Masyriq, 1986

Majalah.Gen.Rahim Khan. Horror of Nuclear War (Pakistan : Defence Journal, 1984)

Munawwir, Ahmad Warson. Al-Munawwir Kamus Arab Indonesia. Yogyakarta : Pondok Pesantren al-Munawwir, 1984

Muhammad. Tinjauan Normatif dan Historis, Jihad dalam Islam. IAIN Sunan Kalijaga : Jurnal Penelitian Agama no 16. TH VI, 1997

Muhammad ibn Ismail Abu Abdullah al-Bukhari, al-Jami' as-shahih ( Beirut: Darul Ibnu Katsir, 1987)

Nasr, Sayyed Hossen. Islam Tradisi di Tengah Kancah Dunia Modern (Bandung : Pustaka 1994) 
Qutb, Sayyid. Tafsir fĩ Zilälil Qur'ān, jilid X. Beirut : Dar al-Fikr, tth

Rahardjo,M Dawam. Ensiklopedia Alquran "Jihad" dalam Ulumul Qur'an no.7 vol.II, 1990

Ash-Shidiqiy, M Hasbi. Sejarah dan Pengantar Ilmu Alquran / Tafsir. Jakarta : Bulan Bintang, 1994

Syamsuddin, Muhammad bin Ali bin Ahmad ad-Dawudi. Tabaqāt alMufassirinn, juz II. Beirut: Dar al-Kutub al-Ilmiah, 1403 / 1983 M

Syamsuddin, Abul Abbas Ahmad bin Muhammad bin Ali Bakr bin Hillikan. Wafaya 'Ayan wa Abnan Abnāiz Zaman. Beirut: Dar as-Shadir, tth

Syirazi, Nasir Makarim. Mendalami Dasar-Dasar Akidah Islam (Jakarta : PT.Raja Grafindo Persada, 1997)

Thabataba'i, Muhammad Husain. Mengungkap Rahasia Alquran, terjemah A.Malik Madani dan Hamim Ilyas. Bandung : Mizan, 1994

Thalib, Ja'far Umar. Jihad fi Sabilillah : Solusi Problematika Bangsa dan Negara Indonesia, dalam Majalah Salafiy, edidi XXXIV / 1421 H. Yogyakarta : Yayasan as-Sunnah, 2000 Panggilan Jihad Membela Muslimin Maluku, dalam Buletin Maluku, edisi 56. Yogyakarta : Komis Dana Lasykar Jihad Korwil DIY, 2000

Umar, Nasaruddin. Antara Jihad, Ijtihad dan Mujahadah. Jakarta : Majalah Sufi, edisi 18, 2001

Wahid, Abdurrahman dkk. Islam Tanpa Kekerasan (Yogyakarta : LkiS, 1998)

Wajdi, Muhammad Farid. Dāirul Ma'ārif al-Qarnil al-Karīm. Kuwait : Dār alBayan, 1972

Az-Zahabi, Muhammad Husain. At-Tafsīr wa al-Mufassirūn, jilid I. Cairo : Dar al-Kutub al-Hadisah, cet II, 1976

Az-Zamakhsyari. Al-Kasysyāf 'an Haqāiqit Ta'wil wa 'Uyūnil Aqāwil fì WujūhitTa'woil, jilid I, II, III, IV. Misr : al-Bāb al-Halabi, 1996 